\title{
arktos \\ Distribution of living benthic foraminifera in the northern Chukchi Sea --Manuscript Draft--
}

Manuscript Number:

Full Title:

Article Type:

Funding Information:

Abstract:

Corresponding Author:
ARCT-D-18-00008R2

Distribution of living benthic foraminifera in the northern Chukchi Sea

Original Article

National Research Foundation of Korea Mr Seung-II Nam

Campus France Mr Jérôme Bonnin

Living (Rose Bengal stained) benthic foraminifera were studied in the topmost sediments of 5 multi- and box cores collected on the continental shelf, upper and lower slopes and of the Chukchi Sea in order to provide background information on modern benthic foraminiferal distribution, useful for future studies. Sediment cores were collected during August-September 2015, when the area is seasonally ice-free. Benthic foraminiferal contents in the 63-125 $\mu \mathrm{m}$ and $>125 \mu \mathrm{m}$ size fractions are discussed in terms of water masses distribution, sedimentological (grain size) and organic geochemical (total organic carbon, total nitrogen, $\mathrm{C} / \mathrm{N}$ ratio and $\delta 13 \mathrm{Corg}$ ) characteristics of the surface sediments. Marine organic carbon-rich clay sediments characterize the faunal microhabitats. Despite relatively high organic carbon contents, standing stocks of living benthic foraminifera are generally low, especially for the 63-125 $\mu \mathrm{m}$ size fraction. This low living stock seems to reflect post-bloom conditions in August and September in the area. The reduced supply of fresh organic carbon also affects faunal microhabitats in the sediment with a concentration of living fauna in the upper $2 \mathrm{~cm}$ of the sediment. Over the Chukchi Sea shelf, a relatively mixed upper sediment layer likely due to bioturbation or bio-structures induce a disturbed vertical distribution in the sediment. Corrosive Pacific-derived bottom water over the shelf likely explains the relative importance of agglutinated vs. calcareous fauna in this shallow setting. Our results suggest that, in a post-bloom context, the main environmental control on benthic foraminiferal assemblages in the Chukchi Sea is the nature of the bottom water masses.

Calypso Racine, doctoral student

Universite de Bordeaux

PESSAC CEDEX, FRANCE

\section{Corresponding Author Secondary} Information:

Corresponding Author's Institution:

Universite de Bordeaux

Corresponding Author's Secondary Institution:

First Author:

Calypso Racine, doctoral student

First Author Secondary Information:

Order of Authors:

Calypso Racine, doctoral student

Jérôme Bonnin

Seung-II Nam

Jacques Giraudeau

Maude Biguenet

Pierre-Antoine Dessandier

Jung-Hyun Kim

Order of Authors Secondary Information:

Author Comments: 
1 Calypso Racine ${ }^{1 *}$, Jérôme Bonnin ${ }^{1}$, Seung- II Nam ${ }^{2}$, Jacques Giraudeau ${ }^{1}$, Maude Biguenet ${ }^{1}$, Pierre-

2
2 Antoine Dessandier ${ }^{3}$, Jung-Hyun $\mathrm{Kim}^{2}$

\section{Distribution of living benthic foraminifera in the northern Chukchi}

\section{Sea}

$5{ }^{1}$ UMR-EPOC 5805 CNRS, Université de Bordeaux, Allée Geoffroy St Hilaire, 33615 Pessac, France

62 Division of Polar Paleoenvironment, Korea Polar Research Institute, 26 Songdomirae-ro, Yeonsu-gu,

721990 Incheon, Republic of Korea

$8{ }^{3}$ CAGE - Centre for Arctic Gas Hydrate, Environment and Climate, Department of Geosciences, UiT

9 The Arctic University of Norway in Troms $\varnothing$, Norway

$10 *$ Corresponding author

11 calypso.racine@u-bordeaux.fr

12 Abstract

Living (Rose Bengal stained) benthic foraminifera were studied in the topmost sediments of 5 multi- and box cores collected on the continental shelf, upper and lower slopes and of the Chukchi Sea in order to provide background information on modern benthic foraminiferal distribution, useful for future studies. Sediment cores were collected during August-September 2015, when the area is seasonally ice-free. Benthic foraminiferal contents in the 63-125 $\mu \mathrm{m}$ and $>125 \mu \mathrm{m}$ size fractions are discussed in terms of water masses distribution, sedimentological (grain size) and organic geochemical (total organic carbon, total nitrogen, $\mathrm{C} / \mathrm{N}$ ratio and $\delta^{13} \mathrm{C}_{\mathrm{org}}$ ) characteristics of the surface sediments. Marine organic carbon-rich clay sediments characterize the faunal microhabitats. Despite relatively high organic carbon contents, standing stocks of living benthic foraminifera are generally low, especially for the 63-125 $\mu \mathrm{m}$ size fraction. This low living stock seems to reflect post-bloom conditions in August and September in the area. The reduced supply of fresh organic carbon also affects faunal microhabitats in the sediment with a concentration of living fauna in the upper $2 \mathrm{~cm}$ of the sediment. Over the Chukchi Sea shelf, a relatively mixed upper sediment layer likely due to 
bioturbation or bio-structures induce a disturbed vertical distribution in the sediment. Corrosive

27 Pacific-derived bottom water over the shelf likely explains the relative importance of agglutinated vs.

28 calcareous fauna in this shallow setting. Our results suggest that, in a post-bloom context, the main

29 environmental control on benthic foraminiferal assemblages in the Chukchi Sea is the nature of the 30 bottom water masses.

\section{Key words}

32 Living benthic foraminifera, Chukchi Sea, water masses, primary production, sea-ice

\section{Acknowledgments}

This study was conducted under the bilateral visiting program between Korea and France funded by Korean Research Foundation (to SIN, 2014K1A3A1A21001427) and the Campus France PHC Star. We thank the captain and crews of the RV Araon. We are very grateful to Sabine Schmidt who performed the ${ }^{210} \mathrm{~Pb}$ analysis and Marie-Claire Perello for the grain size analysis at EPOC. We also thank Kwangkyu Park at KOPRI for the organic geochemical analyses. We wish to thank Jimmy Daynac for the SEM pictures and the photographic plate. P.-A. Dessandier was supported by The Research Council of Norway through its Center of Excellence funding scheme for CAGE, project number 223259. This paper benefited from the very constructive comments of two anonymous reviewers. 


\section{Introduction}

The Arctic Ocean is the smallest and shallowest of the world's five major oceans but it plays an essential role in the global oceanic circulation and the regulation of the Earth's climate system. Since the last decades the Arctic region has undergone significant and rapid climate changes with a reduction of sea-ice cover and thickness, an increase in length of sea-ice melt season (e.g. [20, 44, 55]), as well as a rise in sea surface temperatures (SST) and temperatures of water masses flowing into the Arctic Ocean (e.g. [85, 86, 107, 109]).

Recent benthic foraminifera in the Arctic Ocean have been investigated by several authors during the last five decades $[9,37,41,42,50,64,77,78,79,94,102,103,104]$. The rare studies which distinguished stained (living) benthic foraminifera from fossil (dead) faunas in Arctic sediments usually demonstrate a close correlation between the distribution of foraminiferal species and bottom water masses $[9,37,42,64]$. In the global Ocean, living benthic foraminiferal studies highlight the impact of a wide range of processes upon foraminiferal distributions among which are food supply, salinity, temperature, oxygen, tides and currents, substrate, light penetration, the presence of seagrass and macroalgae, as well as competition and predation ([61] and references therein). Of these multiple factors and in addition to bottom water mass characteristics, food availability and competition for food are thought to control to a high extent foraminiferal associations in the Arctic Ocean (e.g. $[102,103,104])$.

In this paper, we present results from living foraminiferal population collected in the northern sector of the Chukchi Sea, one of the major gateways of the Arctic Ocean. Summer sea-ice in the western Arctic, especially in the Chukchi Sea, has been rapidly declining during the last decades (e.g., [19, 20]). Recently, Yun et al. [111] have also shown that the primary production in the Chukchi Sea presents some decreasing trend for the last decades, probably associated with fresh water input related to sea-ice melting. However, there are very few studies focusing on the distribution of benthic foraminifera in this area. Osterman et al. [64] reported the distribution of benthic foraminifera in the Chukchi Sea but their study was only based on the $>125 \mu$ m size fraction 
and did not distinguish living from dead faunas. Here, we present the first data on the distribution of

71 living benthic foraminifera $>63 \mu \mathrm{m}$ in the northern Chukchi Sea, from the continental shelf to the

lower slope and discuss their distributional pattern in view of the local environmental setting. We believe that the present study is absolutely central for a better knowledge of Arctic foraminiferal ecology and in future efforts aiming at reconstructing past environments in the area of the Chukchi Sea.

\section{Regional setting}

The Chukchi Sea, one of the largest marginal sea of the Arctic Ocean, extends from the Bering Strait in the south to the edge of the Canadian basin in the north (Fig. 1). Most of the Chukchi Sea constitutes a large shallow shelf which deepens progressively towards the north (Fig. 1). To the north of the shelf system, the Chukchi Borderland includes two subsea formations that extend into the Amerasian Basin: the Chukchi Plateau and the Northwind Ridge [68].

The Chukchi Sea is strongly influenced by fresh Pacific waters entering through the Bering Strait. The annual volume transport averages about 0.8 Sv northwards $[71,105]$. This inflow of fresh Pacific waters is stronger in summer and relatively weak in winter. Two water masses of Pacific origin dominate the Chukchi Sea circulation [17]: the Bering Sea Water (BSW) and the Alaskan Coastal Water (ACW). The ACW is carried by the Alaskan Coastal Current (ACC) into the Chukchi Sea, flowing northwards along the Alaskan coast with a transport volume of $0.1 \mathrm{~Sv}$. It is a relatively warm, low salinity and nutrient-poor water mass $[40,106]$. The remaining $0.7 \mathrm{~Sv}$ of Pacific waters flowing into the Chukchi Sea is made of BSW, a mixture of Anadyr Water and Bering Shelf Water [17]. These waters are saltier and richer in nutrients than the ACW [87]. In the western sector of the Chukchi Sea, the seasonal Siberian Coastal Current (SCC; 0.1 Sv) flows southwards along the coast and deflects fresh and cold waters into the central Chukchi Sea [101, 105]. Seasonal variations in Pacific water inflow and sea-ice cover lead to a seasonal cycle of water mass stratification $[40,105]$. In summer, the inflow of Pacific water, especially via the ACC, transports heat into the Chukchi Sea leading to a stronger stratification of the surface layers [108]. Conversely, water column is well-mixed from fall to 
spring, the inflow of Pacific water becoming cooler and denser due to brine releases during sea-ice

97 formation [100]. To the north of the Chukchi Shelf, surface circulation is driven by the two main 98 surface current systems of the Arctic Ocean: the Beaufort Gyre (BG) and the Transpolar Drift (TPD).

Warm and salty Atlantic Intermediate Water (AIW) flows along the Chukchi slope, following the shelf break from west to east, between approximatively 200 and 900 meters below sea level, and submerges cold Arctic Deep Water (ADW) which circulates within the deep Arctic basins (Fig.1; [1, 13, 91]).

The Chukchi Sea is characterized by a first-year ice, making this area particularly sensitive to the present overall reduction in Arctic sea-ice concentration $[18,24]$. Over the satellite record, the Chukchi Sea has displayed the sharpest downward trends in Arctic sea-ice extent, the September seaice edge being now located far north of the continental shelf break [20]. Shimada et al. [85] and more recently Serreze et al. [83] suggested that the recent reduction in sea-ice concentration was essentially triggered by the warming of the inflowing Pacific water. Atmospheric temperature and circulation may also influence the seasonal melting of ice [83].

The Chukchi Sea is generally considered as a highly productive region on the edge of the largely oligotrophic Arctic basin [57] as the result of the inflow of fresh and nutrient-rich Pacific water into the Chukchi continental shelf. However, a recent study by Yun et al. [111] has shown a decreasing trend in primary production in the Chukchi Sea during the last decades with relatively large regional variation. Spatial and temporal variations in the productivity of the Chukchi Sea are related to changes in duration, thickness and extent of seasonal sea-ice which control light availability and surface water stratification from sea-ice melting [36, 39, 98, 111]. Mean average primary productivity in the Chukchi Sea is generally higher over the shallow shelf which experiences seasonal sea-ice compared to the northern sector of the Chukchi Sea [111]. Primary production rates over the southern shallow sector of the Chukchi Sea average $80-90 \mathrm{~g} \mathrm{C} \mathrm{m}^{-2} \mathrm{y}^{-1}$ and progressively decrease toward the slope $\left(<50 \mathrm{~g} \mathrm{C} \mathrm{m}^{-2} \mathrm{y}^{-1}\right)$ and over the deep Arctic basin $\left(<20 \mathrm{~g} \mathrm{C} \mathrm{m}^{-2} \mathrm{y}^{-1}\right)$ [36, 39, 74, 98]. Intense blooms are observed with ice edge retreat [97], in the open water of marginal ice 
122 zone (MIZ; [65]), starting with an ice algae bloom in May followed by a strong but brief

phytoplankton bloom in June [99]. A recent study also revealed intense phytoplankton blooms beneath sea-ice in the Chukchi Sea [2]. However, several studies show the negative effect of fresh water input resulting from sea-ice melting on the nutrient concentration and therefore primary production in this area $[22,110,111]$.

\section{Materials and methods}

\subsection{Sample collection}

This study is based on $9.8 \mathrm{~cm}$ diameter multicores and push cores subsampled from boxcores collected at five stations in the Chukchi Sea during the ARA06C cruise onboard the RV ARAON, between August $25^{\text {th }}$ and September 9 $9^{\text {th }}, 2015$ (Fig. 1, table 1). Upon recovery, sediment cores were sliced onboard every $0.5 \mathrm{~cm}$ from the surface down to $2 \mathrm{~cm}$, then every centimetre down to $5 \mathrm{~cm}$. For each station, one sediment core was used for benthic foraminiferal analysis and another one for sedimentological and geochemical analyses. Temperature and salinity profiles through the whole water column, as well as chlorophyll a $(\mathrm{Chl} a)$ profiles for the upper water column were measured at Sts. 01A, 02, 03 and 04 using a conductivity temperature depth (CTD) profiler and a fluorometer sensor respectively. Sea-ice conditions (drift ice) hindered the deployment of the profiler at St. 05.

\subsection{Sedimentological and geochemical analyses}

Grain size analysis were conducted at Environnements et Paléoenvironnements Océaniques et Continentaux (EPOC, France) using a laser diffraction particle size analyser (Malvern Mastersizer 2000 hydro G). Measurements along the top $5 \mathrm{~cm}$ of each core were performed on freeze-dried sediment. Grain size-spectra derived from downcore measurements display a unimodal distribution at all stations. We therefore consider the median diameter of the particle size distribution $D_{50}$ as a reliable measurement of the mean grain size in the sediment cores investigated in the present study. Sedimentary total organic carbon (TOC) and total nitrogen (TN) contents as well as stable isotope composition of organic carbon $\left(\delta^{13} \mathrm{C}_{\mathrm{org}}\right)$ were measured at the Korea Polar Research Institute 
147 (KOPRI, South Korea) using an EA-IRMS system (Flash 2000-Delta V, Thermo Scientific). Total carbon

(TC) and TN were measured on freeze-dried sediment. TOC and $\delta^{13} C_{\text {org }}$ were analysed on carbonate free sediment after $\mathrm{HCl}(10 \%)$ treatment. Finally, TOC was calculated using the following equation [88]: TOC $(\%)=[100-(8.333 *$ TC $)] /\left[\left(100 /\right.\right.$ TOC $\left.\left.^{\prime}\right)-8.333\right]$. The analytical error was less than $\pm 0.1 \%$ for TN and TOC contents and $\pm 0.1 \%$ for $\delta^{13} \mathrm{C}_{\text {org. }}$. TN and TOC are expressed as the mass weight of dry bulk sediment (wt. \%). The C/N ratio was calculated by dividing TOC by TN.

${ }^{210} \mathrm{~Pb}$ and ${ }^{226} \mathrm{Ra}$ were measured at EPOC (France) by $\curlyvee$ spectrometry analytical technique on freeze-dried sediment of the first $7 \mathrm{~cm}$ of core $01 \mathrm{~A}$ (St. $01 \mathrm{~A}) .{ }^{210} \mathrm{~Pb}$ in excess of equilibrium with ${ }^{226} \mathrm{Ra}$, ${ }^{210} \mathrm{~Pb}_{\mathrm{xs}}$, was calculated as the difference between measured ${ }^{210} \mathrm{~Pb}$ and ${ }^{226} \mathrm{Ra}$.

\subsection{Living (stained) benthic foraminiferal analysis}

Sample treatment and faunal analysis mostly follow the FOBIMO standardized protocol [76]. Benthic foraminiferal samples were preserved in a $1.5 \mathrm{~g} \mathrm{~L}^{-1}$ solution of Rose Bengal in $96 \%$ ethanol in order to stain the living endoplasm of benthic foraminifera according to Murray and Bowser [60] and Walton [96]. This concentration is lower than recommended by the FOBIMO protocol $\left(2 \mathrm{~g} \mathrm{~L}^{-1}\right)$, but has been shown to efficiently stain the living organism in many studies [e.g., 25, 28]. The samples were repeatedly homogenised immediately after staining. For more precision, the real volumes of sediment were measured [76]. Samples were wet sieved through $63 \mu \mathrm{m}$ and $125 \mu \mathrm{m}$ mesh screens. Benthic foraminiferal analysis was performed on both the 63-125 $\mu \mathrm{m}$ and $>125 \mu \mathrm{m}$ size fractions. All stained individuals were hand-sorted under wet condition from the surface down to $5 \mathrm{~cm}$ for the $>125 \mu \mathrm{m}$ fraction and from the first centimetre only for the 63-125 $\mu \mathrm{m}$ fraction. The choice of limiting the analysis of the $63-125 \mu \mathrm{m}$ fraction to the top first centimetre stems from the extremely low abundance of living fauna in the $0-1 \mathrm{~cm}$ interval of this size fraction at each investigated station (precluding the existence of $<125 \mu \mathrm{m}$ fauna below the depth of $1 \mathrm{~cm}$ ) as well as from the time consuming effort for such low gain. The coloration of Rose Bengal stained specimens considered as 171 living at the time of sampling may vary among species from light pink to dark red or brownish violet 172 [76]. Consequently, only specimens with all chambers coloured (except the last one) were considered 
as living. Some non-transparent tests (miliolids or agglutinated taxa) were broken, after

identification, to ensure that protoplasm was stained. All specimens were identified to species levels if possible following the generic classification of Loeblich and Tappan [51].

We considered as major species the ones representing at least $5 \%$ of the foraminiferal assemblages. Faunal densities were standardized for a sediment volume of $50 \mathrm{~cm}^{3}$. Living standing stock represents the total number of living individuals counted per station in each size fraction, normalized for a $100 \mathrm{~cm}^{2}$ sediment area according to Goineau et al. [31] and Dessandier et al. [25]. Three biodiversity indices were calculated using the PAST software [38]: the species richness (S, number of species present in a sample), the Shannon index $H^{\prime}$ [84] and the Evenness index E [12].

\section{Results}

\subsection{Environmental, sedimentological and organic geochemical settings}

\section{during the sampling period}

At the end of August 2015, sea-ice was very thin and was only found north of the sampling area (Fig. 1). A continuous northward retreat of the sea-ice edge occurred until the end of September 2015. Therefore, all the investigated stations were free of ice at the time of sampling.

An upper $20 \mathrm{~m}$ thick low salinity $(<30)$ surface layer characterizes all stations under the influence of sea-ice melting (Fig. 2a). Changes toward lower surface salinities (ca. 29.5 to 26.5) and lower surface temperatures (ca. 1.5 to $-1^{\circ} \mathrm{C}$ ) from St. $01 \mathrm{~A}$ to St. 04 reflect the increasing proximity to the sea-ice edge. This surface mixed layer overlays the colder and saltier Pacific water with typical signature of $-1.5^{\circ} \mathrm{C}$ and 33 extending down to $200-250 \mathrm{~m}$ over the slope and deep sectors of the Chukchi Sea (Fig. 2a). This water mass bathes the sediment-water interface at the shallow $(110 \mathrm{~m})$ St. 01A (Fig. 2a). The AIW with mean salinities of 35 and temperatures up to $0.8-0.9^{\circ} \mathrm{C}$ is observed from 200-250 m to ca. $750 \mathrm{~m}$ (Fig. 2a), and therefore characterizes the bottom water at the slope Sts. 05 $(350 \mathrm{~m})$ and $03(750 \mathrm{~m})$. The ADW occupies the deeper $>750 \mathrm{~m}$ water column at Sts. $02(2100 \mathrm{~m})$ and $04(2300 \mathrm{~m})$ with typical temperatures $<0^{\circ} \mathrm{C}$ and stable salinity of 35 (Fig. 2a). Chl $a$ profiles within the 
upper water masses of Sts. 01A, 03, 02 and 04 are given in Figure 2b. Chl a concentrations measured at all stations range from ca. 0.5 to $1.6 \mu \mathrm{g} \mathrm{L}^{-1}$ within the top $80-100 \mathrm{~m}$ water depth. These values are relatively low when compared to values of $\mathrm{Chl} a$ concentrations (about 1-10 $\mu \mathrm{g} \mathrm{L}^{-1}$ ) commonly measured in the study area during bloom periods in June and July $[2,65,97]$. Maximum $\mathrm{Chl} a$ concentrations over the shelf (St. 01A; 0.6-0.7 $\mathrm{g} \mathrm{L} \mathrm{L}^{-1}$ ) occur in shallower depth, around $20 \mathrm{~m}$ water depth, than over the upper and lower slope stations (Sts. 03, 02, 04) where peak values of 0.6 to 1.6 $\mu \mathrm{g} \mathrm{L^{-1 }}$ are found deeper around 60-70 $\mathrm{m}$ water depth.

Sedimentological and geochemical analyses in the surface sediment are shown in Figure 3. At all stations, sediment grain size ranges from clay to fine silt $\left(D_{50}=8-12 \mu \mathrm{m}\right)$. The shallowest St. 01A displays high TOC and TN contents ( $>2.5$ and 0.3 wt. $\%$, respectively) compared to other stations ( $\leq 1$ and $0.15 \mathrm{wt}$. \%). The $\delta^{13} \mathrm{C}_{\text {org }}$ values range from -24 to $-21 \%$ and agree with other evidences [36, 62, 63] for a dominant marine origin of the organic matter in sediments of the Chukchi Sea and more generally in sediments of the Amerasian Arctic. This marine origin is confirmed by the $\mathrm{C} / \mathrm{N}$ ratio which, within the top $2 \mathrm{~cm}$ of most of the stations, ranges between 6 and 8 , revealing typical signature of marine algae [70]. These ratios also indicate that this marine organic matter was subjected to limited degradation processes within the water column and the top part of the sediment layers [56]. $\mathrm{C} / \mathrm{N}$ ratio values close to 9 on average at St. 01A however suggest that sediment at this shelf station might contain a terrigenous component, though with limited contribution to the total organic matter content. ${ }^{210} \mathrm{~Pb}_{\mathrm{xs}}$ activity profile (Fig. 4) was measured in the 217 first $7 \mathrm{~cm}$ of the sediment in order to highlight possible bioturbation or bio-structures in core $01 \mathrm{~A}$ 218 locating on the shelf. The vertical profile of ${ }^{210} \mathrm{~Pb}_{\mathrm{xs}}$ shows relatively stable values down to $6 \mathrm{~cm}$ and a 219 gently decrease below.

$220 \quad$ 4.2. Living benthic foraminifera 
show any mark of alteration or dissolution. Living faunal standing stocks show extremely low values in the $63-125 \mu \mathrm{m}$ size fraction, from 0 ind./100 $\mathrm{cm}^{2}$ in the shallowest St. $01 \mathrm{~A}$ to 11 ind. $/ 100 \mathrm{~cm}^{2}$ in St. 03 (Fig. 5a and Fig. 7). For this 63-125 $\mu \mathrm{m}$ fraction, excluding St. $03(750 \mathrm{~m}), \mathrm{H}^{\prime}$ therefore equals 0 and E equals 1 for all stations due to the presence of only one living species (Fig. $5 c$, d). Benthic foraminiferal standing stocks and diversities $S$ are generally higher in the $>125 \mu \mathrm{m}$ size fraction, ranging from 8 to 297 ind./100 $\mathrm{cm}^{2}$, and from 3 to 17 species, respectively, with higher values generally measured at the shallowest stations (Fig. 5a, b). Lowest standing stocks are observed at the deepest stations ( 8 and 18 ind./100 $\mathrm{cm}^{2}$ at Sts. 02 and 04 , respectively). $\mathrm{H}^{\prime}$ and $\mathrm{E}$ values do not indicate any clear correlation with water depth (Fig. 5c, d). Both indices are minimal at the mid-depth station (St. 03, $750 \mathrm{~m}$ ).

\subsubsection{Relative abundances of the dominant species}

Because of the extremely low living standing stock in the $63-125 \mu \mathrm{m}$ size fraction, relative abundances and comparison between size fractions should be considered with great care. Except at St. 03, only calcareous taxa are found in the 63-125 $\mu \mathrm{m}$ fraction (Fig. 6a). In the $>125 \mu \mathrm{m}$ fraction, the contribution of agglutinated taxa is decreasing with increasing water depth, ranging from $40 \%$ at St. $01 \mathrm{~A}$ to 0 at Sts.02 and 04 (Fig. 6b). With the exception of the deepest St. 04 where Oridorsalis tenerus shows high relative abundances in both size fractions, species assemblages are drastically different between size fractions (Fig. 7). Some species observed in the small size fraction are however worth mentioning: Parafissurina tectulostoma and O. tenerus are found on the upper slope (Sts. 05 and 03) and in the lower slope (Sts. 02 and 04). Higher standing stocks in the $>125 \mu \mathrm{m}$ fraction support a more robust description of the species assemblages. Elphidium excavatum subsp. clavatum and Nonionellina labradorica, both calcareous species, are the dominant taxa (45 and $13 \%$, respectively) 246 in shelf sediments (St. 01A, Fig. 7b). Subordinate agglutinated species consist of Saccammina sp., Labrospira crassimargo, Nonionina scapha var. arenacea and Recurvoïdes contorta. Upper and lower 248 slope stations are characterized by distinct foraminiferal populations. Foraminiferal assemblages at 249 upper slope stations are both overwhelmingly (>60\%) dominated by Cassidulina neoteretis. 
Elphidium excavatum subsp. clavatum and Lagenammina arenulata are present (27\% and $7 \%$, respectively), at St. $05(350 \mathrm{~m})$ though both species are absent in the other upper slope St. 03 (750 m). In both deepest Sts. 02 and 04, loanella tumidula and Triloculina oblonga are common to abundant (Fig. 7b). Oridorsalis tenerus is dominant (64\%) at the deepest station (St. 04) but not observed at St. 02.

\subsubsection{Vertical distribution}

The vertical distribution $(0$ to $5 \mathrm{~cm}$ ) of living foraminifera was analysed for the $>125 \mu \mathrm{m}$ size fraction only (Fig. 8). Benthic foraminifera are generally concentrated in the upper $2 \mathrm{~cm}$ of the sediment with density reaching up to 133 and 386 ind. $/ 50 \mathrm{~cm}^{3}$ in the top-most layer $(0-0.5 \mathrm{~cm})$ of Sts. 03 and 05, respectively. At the shallowest St. 01A, the highest faunal density is also observed in the top-most layer with 47 ind./50 $\mathrm{cm}^{3}$ and abundant agglutinated species, among which L. crassimargo and N. scapha var. arenacea. However, contrary to other stations, living faunas are found down to 5 $\mathrm{cm}$, with E. excavatum subsp. clavatum reaching up to 28 ind./50 $\mathrm{cm}^{3}$ in the $4-5 \mathrm{~cm}$ layer. Nonionellina labradorica shows its higher abundances between 1 and $2 \mathrm{~cm}\left(12\right.$ ind./50 $\left.\mathrm{cm}^{3}\right)$.

\section{Discussion}

In most studies where benthic foraminifera from 63-125 $\mu \mathrm{m}$ and $>125 \mu \mathrm{m}$ size fractions are hypothesis, the occurrence of well stained individuals in the $>125 \mu \mathrm{m}$ size fraction suggests that the 274 extremely low density in the 63-125 $\mu \mathrm{m}$ fraction is a consequence of environmental conditions rather 
than a methodological bias. Density of dead fauna was assessed on the top centimetre $(0-1 \mathrm{~cm})$ of the sediment for the $63-125$ and $>125 \mu \mathrm{m}$ fractions in order to test whether the distribution of living fauna according to the size fractions is representative of mean average conditions in the studied area. Living and dead faunal densities are shown for both fractions in Figure 9. Not surprisingly given the time interval represented by the accumulation of dead fauna ( 25 years at least considering a minimal sedimentation rate of $0.4 \mathrm{~mm} / \mathrm{yr}$ [23]), the density of the dead fauna is much higher than that of the living fauna, especially for the $63-125 \mu \mathrm{m}$ size fraction. Furthermore, the density of the dead fauna shows highest values in the lower slope Sts. 02 and 04 while the living fauna are more abundant in the upper slope Sts. 03 and 05 . The remobilization and transport of dead fauna by active currents from shallow to deep settings [23] as well as taphonomical processes leading to the dissolution of calcareous forms that dominate the living assemblage at shallow stations [e.g., 89] might in part explain the observed discrepancy. More presumably, we consider that the sampling period (late August to early September 2015) is not typical of normal late summer environmental conditions in the Chukchi Sea and/or that the peak production of benthic foraminiferal species which contribute to the 63-125 $\mu \mathrm{m}$ fraction does not occur over late summer. Our data does not permit us to deal further with this issue. Therefore, and despite the relatively high proportion of dead foraminifera in the 63-125 $\mu \mathrm{m}$ fraction, most of the following discussion on the distribution of the living benthic foraminifera will be based on the $>125 \mu \mathrm{m}$ fraction only.

\subsection{Density and diversity of living benthic foraminifera related to} primary production

Except at St. 01A, where bottom temperature and salinity are $-1.5^{\circ} \mathrm{C}$ and 33.1 respectively, these two parameters display similar values at all other stations, ranging from 0.2 to $-0.5^{\circ} \mathrm{C}$ and close to 35.0 (Fig. 2a). Wollenburg and Mackensen $[102,103]$ have shown that among the various factors controlling the distribution of benthic foraminifera in the Arctic, bottom water mass characteristics are of minor importance. Likewise, given the equivalent grain size measured at all stations (clay to fine silt), we do not consider this sedimentological parameter as influential in explaining the 
observed heterogeneities in species assemblages among stations (Fig. 3). The distribution of living benthic foraminifera is well known to be influenced by biotic and abiotic factors, among which the oxygen concentration and food supply are the most important $[45,102,103]$. TOC values in the studied upper and lower slope stations are fairly stable, ranging from 0.6 to $1.2 \%$, and agree with values found by Husum et al. [41] for the central Arctic. Over the shelf (St. 01A), TOC reaches $2.6 \%$. However, the standing stock at St. 01A is not particularly high compared with other stations, pointing out the influence of other parameters than organic matter content alone. Recent studies suggest that the quality and origin of the organic matter delivered to the seabed play a major role in controlling benthic foraminiferal ecology $[25,28,29,32,46,75]$. The major food source for benthic foraminifera in the open ocean is organic matter derived from primary production. In the Arctic Ocean, food availability and benthic foraminiferal standing stock, composition and vertical distribution in sediments will greatly depend on sea-ice seasonality (e.g., $[41,102,103])$. In the Chukchi area, the marine primary production, and thus the export of organic matter to bottom sediments, is essentially controlled by nutrients availability, seasonal sea-ice extent (e.g., [93]), light penetration and fresh water input variability $[22,111]$, these parameters being strongly related. 316 Many studies suggest that nitrogen availability through nitrate supply tends to control and limit 317 primary productivity in seasonally ice-covered waters of the Arctic Ocean $[58,74,92]$. Tremblay et al. 318 [93] showed a clear difference between the Chukchi shelf and Chukchi borderlands in terms of 319 nitrate maximum at the surface due to perennial stratification in the interior sector. Yun et al. [111] 320 also showed that primary production is highest in the southern Chukchi Sea and decreases 321 northward as a result of sea-ice cover and meltwater input mainly. In this study, abundance and 322 diversity are lower in the deepest stations (Sts. 02 and 04) that in the shelf and upper slope stations 323 (Sts. 01A, 05 and 03). The living foraminiferal density in the $>125 \mu \mathrm{m}$ size fraction at all stations (Fig. 324 8) remains however low (from 4 ind. $/ 50 \mathrm{~cm}^{3}$ at St. 02 to 454 ind. $/ 50 \mathrm{~cm}^{3}$ at St. 05 for the upper 325 centimetre) in comparison to other studies in Arctic environments. Wollenburg and Mackensen [103] 326 reported living benthic foraminiferal densities in the same size fraction ranging from $18 \mathrm{ind} . / 50 \mathrm{~cm}^{3}$ in 
the deep Nansen Basin to 1044 ind./50 $\mathrm{cm}^{3}$ on the Yermak Plateau. Husum et al. [41] using a slightly smaller size fraction $(100 \mu \mathrm{m}-1 \mathrm{~mm})$ provided density values of 0 ind. $/ 50 \mathrm{~cm}^{3}$ on the Alpha and Gakkel Ridge and more than 6300 ind. $/ 50 \mathrm{~cm}^{3}$ on the Kara Sea continental margin. The north of the Chukchi Sea is covered by sea-ice 8 months a year from November to June [e.g., 82, 90]. Long sea-ice cover leads to a generally low primary productivity and organic matter flux reducing the living benthic foraminiferal standing stock and the faunal habitat depths in the sediment $[11,69]$. Although the sea-ice cover at the time of sampling was scarce for the northernmost deep stations, this may, at least partly, explain the standing stock differences between the relatively rich outer-shelf, upper slope stations and the very poor lower slope stations (Fig. 7). During summer in the Chukchi Sea, heterotrophic processes take over autotrophic processes following nutrient depletion by the spring bloom $[39,99]$. This feature induces a seasonal shift in the quantity and the quality of the vertically exported biogenic matter. The biogenic matter exported is high and fresh in spring while it becomes lower and more degraded (faecal pellets, aggregates, detritus) in summer, especially during August and September [99]. Chlorophyll data measured at the deepest stations of the Chukchi Sea, however, show a relatively well-developed subsurface Chlorophyll maximum (SCM) centred around $60 \mathrm{~m}$ with chl $a$ values reaching $1.6 \mu \mathrm{g} \mathrm{L}-1$. The depth and values of this SCM agree with the results of Coupel et al. [22] for the Chukchi area and Martin et al. [54] for other Arctic seas. Therefore, surface or subsurface productivity might not be the only limiting factor there.

\subsection{Species distribution as a proxy of environmental changes}

In the 5 studied cores, distinct living benthic foraminiferal assemblages are observed

according to the following bathymetric ranges as: outer shelf (110 m water depth), upper slope (350$750 \mathrm{~m})$ and lower slope (2100-2300 m). The outer shelf assemblage is found where organic matter

content is the highest (Fig. 3). The most abundant species in this assemblage are E. excavatum subsp.

clavatum, N. labradorica, L. crassimargo and R. contorta. Elphidium excavatum subsp. clavatum is a typical shelf species [61] and was found abundant in surface sediment over the Chukchi shelf [64] although this cited study did not distinguish living from dead fauna. Other species in this assemblage 
such as $N$. labradorica are either linked to elevated fluxes of fresh phytodetritus $[14,21,67]$ or associated to high contents of buried organic matter [21]. Phytoplankton bloom in this area typically occurs in late June-early July [2], two months before the sampling period. High TOC (Fig. 3) and the vertical distribution of $N$. labradorica at this station (Fig. 8) rather suggest the latter case in the present study. From a study conducted over the Kamchatka slope, Bubenshchikova et al. [11] described $N$. labradorica as an abundant intermediate infaunal species in the sea-ice free mesotrophic zone. The benthic foraminiferal population observed at the shelf St. $01 \mathrm{~A}$ is made of 40 $\%$ of agglutinated specimens, peaking to $70 \%$ in the topmost centimetre (Fig. 8). This calcareous/agglutinated assemblage is typical of shallow Arctic and subarctic environments [41, 49, $50,64,104]$. In the Chukchi Sea, several authors observed undersaturated seawater $p \mathrm{CO} 2$ during the sea-ice free period across the shelf $[3,4,5,15,16,30,59,66,81]$. In contrast, subsurface seawater pCO2 values were highly oversaturated $[3,6]$. These observations are indicative of an efficient organic carbon remineralization in the subsurface waters and into the sediment of the Chukchi continental shelf. Organic carbon remineralization increases $\mathrm{pCO} 2$ and decreases the $\mathrm{pH}$. This process contributes to the acidification of interstitial waters making them further corrosive and leading to partial carbonate dissolution $[7,8]$ which could explain the recorded high abundance of agglutinated species on the shelf sediment of the Chukchi Sea.

The upper slope assemblage is highly dominated by $C$. neoteretis. Elphidium excavatum subsp. clavatum is dominant only on the upper slope St. 05. Cassidulina neoteretis is a shallow infaunal species associated to AIW in the Arctic $[41,42,64]$ and typically related to fresh input of phytodetritus [34, 53]. Additionnaly, and although based only on quick visual examination of dead faunas, we notice that $C$. neoteretis that is dominating the living fauna at Sts. 03 and 05 is completely 375 absent in the dead fauna. Cassidulina, a typically opportunistic genus, is however generally more 376 abundant in dead assemblages than in living populations in various settings of the world ocean as a 377 consequence of high production rates and short living time [26]. Our paradoxical observations may 378 be related to dissolution in sediment by corrosive interstitial water or active transport by bottom 
currents directly after the death of the organisms as already suggested earlier to explain higher density of the dead fauna at deep stations. The presence of this species, indicator of modified Atlantic Water/Arctic Intermediate Water [43], in the living fauna only may also suggests very recent changes in the local hydrology. Elphidium excavatum subsp. clavatum was observed by Korsun and Hald [47] in the Tempelfjorden in Svalbard and seems to be related to increasing glacier meltwater discharge. It is a widespread species in Arctic shelves with ability to colonize harsh environments (e.g., [21]). Its presence in the living fauna (Fig. $7 \mathrm{~b}$ and 8 may therefore suggest high meltwater supply from sea-ice at the location of Sts.01A and 05.

The deep assemblage is essentially made of the surface infaunal species $O$. tenerus and $I$. tumidula. loanella tumidula dominates St. 02 at 2100 m while 0 . tenerus is absent. Oridorsalis tenerus is overwhelmingly dominant at the deepest St. 04 . Note that $O$. tenerus is the only species found at both Sts. 02 and 04 in the $63-125 \mu \mathrm{m}$ fraction. Oridorsalis tenerus and I. tumidula (as Eponides tumidulus) were found in the same biofacies by Ishman and Foley [42] at water depths greater than $1300 \mathrm{~m}$ in the Canada Basin. Husum et al. [41] also found these species in the 13003700 m water depth interval, on the permanently ice-covered Lomosov Ridge and Alpha Ridge in addition to the seasonally ice-free Nansen Basin. They are therefore referred as typically oligotrophic species. Wollenburg and Mackensen [102] however suggest that $O$. tenerus is better adapted to more oligotrophic conditions. Lower TOC values at St. 04 , where 0 . tenerus is dominant, compared to St. 02 well supports this idea.

The vertical distribution of the living fauna (Fig. 8) shows sharp decrease below the first 399 centimetre with the topmost layer being normally the richest, except at St. 02 where no living 400 individuals where found in this upper layer. This is very consistent with other studies on the 401 distribution of living benthic foraminifera in the Arctic. Wollenburg and Mackensen [103] found living 402 individuals down to $8 \mathrm{~cm}$ while in the central Arctic most of the fauna was concentrated in the upper $4032 \mathrm{~cm}$ according to the very low flux of organic matter in this permanently ice-covered area. The 404 sampling period during post-bloom conditions, as well as the relatively low TOC values measured in 
sediments of the upper and lower slope stations suggest that a weak input of labile organic matter in this sector of the Chukchi Sea induced the observed shallow (upper $2 \mathrm{~cm}$ ) habitat of benthic foraminifera. The shallow St. 01A is characterized by a subsurface peak in foraminiferal density between 1 and $3 \mathrm{~cm}$ with $N$. labradorica, an intermediate infaunal species [61] as the dominant taxa. The presence of E. excavatum subsp. clavatum, a shallow infaunal species between 3 and $5 \mathrm{~cm}$ at St. 01A suggests local bioturbation or bio-structures. The occurrence at this station of several macroorganisms such as bivalves and echinoderms as well as a homogeneous ${ }^{210} \mathrm{~Pb}_{\mathrm{xs}}$ activity profile (Fig. 4) showing relatively stable values down to $6 \mathrm{~cm}$ confirms the possible bioturbation or bio-structure systems created by the activity of macro-/meio-fauna. On one hand, bioturbation might explain the unusual occurrence of E. excavatum subsp. clavatum deeper than expected. On the other hand, the presence of bio-structures leads to particular biochemical conditions and biotic associations which offer microhabitats favourable for the development of benthic foraminifera traditionally found in another range of sediment depth [52] such as E. excavatum subsp. clavatum.

\section{Conclusions}

This study aims to describe and understand the distribution of living benthic foraminifera in the northern Chukchi Sea continental shelf, upper and lower slope, an Arctic environment strongly impacted by recent climate changes. According to our observations, various environmental factors may influence the benthic foraminiferal abundance, composition and vertical distribution in the Chukchi Sea.

(1) The distributional patterns of living faunal assemblages seems to reflect the nature of the bottom water masses according to the three bathymetric sectors of the Chukchi Sea investigated in the present study. Over the shelf bathed by the corrosive Pacific water agglutinated specimens are abundant. Here, the assemblage is dominated by the calcareous species E. excavatum subsp. clavatum and $N$. labradorica and the agglutinated species $L$. crassimargo and R. contortus. Over the Chukchi slope, under the influence of Atlantic waters, 
the assemblage is overwhelmingly dominated by $C$. neoteretis. Benthic foraminiferal populations in deep stations bathed by Arctic water are dominated by I. tumidula and $O$. tenerus.

(2) The overall low faunal diversity and standing stock at all stations may reflect post-bloom conditions in late August and early September in the area, and hence reduced supply of fresh organic matter to the sea floor. Living standing stocks are much lower in the $63-125 \mu \mathrm{m}$ size fraction than in the $>125 \mu \mathrm{m}$ fraction. Although a methodological bias cannot be completely excluded, we believe that the conditions at the time of sampling were oligotrophic with highly degraded organic matter that does not favour the presence of opportunistic species often found in the small fraction.

(3) Our results suggest that in the context of post-bloom conditions, the lower quality of exported organic matter might also explain the observed, exclusively shallow (topmost centimetre) habitat of living benthic foraminifera in sediments of the upper and lower slope. The apparently deepest habitat (down to $5 \mathrm{~cm}$ ) found over the shelf is probably related to intense bioturbation or bio-structures in this shallow setting, as evidenced by the presence of typical surface dwellers down in the sediment column.

Our study brings several hypothesis on the ecology and preservation of benthic foraminiferal 448 fauna in the northern Chukchi Sea, confirming the key information that this species group can 449 provide about modern and past changes in Arctic circulation and climate. 
1. Aagaard K, Swift JH, Carmack EC (1985) Thermohaline circulation in the Arctic Mediterranean seas. Journal of Geophysical Research 90(C3):4833-4846

2. Arrigo KR, Perovich DK, Pickart RS, Brown ZW, Van Dijken GL, Lowry KE et al (2014) Phytoplankton blooms beneath the sea ice in the Chukchi Sea. Deep Sea Research Part II: Topical Studies in Oceanography 105:1-16

3. Bates NR (2006) Air-sea $\mathrm{CO}_{2}$ fluxes and the continental shelf pump of carbon in the Chukchi Sea adjacent to the Arctic Ocean. Journal of Geophysical Research: Oceans 111(C10)

4. Bates NR, Best MH, Hansell DA (2005) Spatio-temporal distribution of dissolved inorganic carbon and net community production in the Chukchi and Beaufort Seas. Deep Sea Research Part II: Topical Studies in Oceanography 52(24-26):3303-3323

5. Bates NR, Moran SB, Hansell DA, Mathis JT (2006) An increasing $\mathrm{CO}_{2}$ sink in the Arctic Ocean due to sea-ice loss. Geophysical Research Letters 33(23)

6. Bates NR, Mathis JT, Cooper LW (2009) Ocean acidification and biologically induced seasonality of carbonate mineral saturation states in the western Arctic Ocean. Journal of Geophysical Research: Oceans 114(C11)

7. Bates NR, Mathis JT (2009) The Arctic Ocean marine carbon cycle: evaluation of air-sea $\mathrm{CO}_{2}$ exchanges, ocean acidification impacts and potential feedbacks. Biogeosciences 6(11):24332459

8. Bates NR, Garley R, Frey KE, Shake KL, Mathis JT (2014) Sea-ice melt $\mathrm{CO}_{2}$-carbonate chemistry in the western Arctic Ocean: Meltwater contributions to air-sea $\mathrm{CO}_{2}$ gas exchange, mixed-layer properties and rates of net community production under sea ice. Biogeosciences 11(23):6769

9. Bergsten H (1994) Recent benthic foraminifera of a transect from the North Pole to the Yermak Plateau, eastern central Arctic Ocean. Marine Geology 119(3-4):251-267

10. Brady HB (1884) Report on Foraminifera (9). HM Stationery Office 
11. Bubenshchikova N, Nürnberg D, Lembke-Jene L, Pavlova G (2008) Living benthic foraminifera of the Okhotsk Sea: Faunal composition, standing stocks and microhabitats. Marine Micropaleontology 69(3-4):314-333

12. Buzas MA, Gibson TG (1969) Species diversity: benthonic foraminifera in western North Atlantic. Science 163(3862):72-75

13. Carmack, EC (1990) Large-scale physical oceanography of Polar Oceans. In: WO Smith Jr (ed) Polar Oceanography Part A, Academic Press, San Diego, CA, USA pp 171-212

14. Cedhagen, T (1991) Retention of chloroplasts and bathymetric distribution in the sublittoral foraminiferan Nonionellina labradorica. Ophelia 33(1):17-30

15. Chen L, Gao Z (2007) Spatial variability in the partial pressures of $\mathrm{CO}_{2}$ in the northern Bering and Chukchi seas. Deep Sea Research Part II: Topical Studies in Oceanography 54(23-26):2619-2629

16. Chierici M, Fransson A (2009) Calcium carbonate saturation in the surface water of the Arctic Ocean: undersaturation in freshwater influenced shelves. Biogeosciences 6(11):2421-2431

17. Coachman LK, Aagaard K, Tripp RB (1975) Bering Strait: the regional physical oceanography. University of Washington Press

18. Comiso JC (2002) A rapidly declining perennial sea ice cover in the Arctic. Geophysical Research Letters 29(20)

19. Comiso JC, Parkinson CL, Gersten R, Stock L (2008) Accelerated decline in the Arctic sea ice cover. Geophysical research letters 35(1)

20. Comiso JC (2012) Large decadal decline of the Arctic multiyear ice cover. Journal of Climate 25(4):1176-1193

21. Corliss BH (1991) Morphology and microhabitat preferences of benthic foraminifera from the northwest Atlantic Ocean. Marine micropaleontology 17(3-4):195-236

22. Coupel P, Ruiz-Pino D, Sicre MA, Chen JF, Lee SH, Schiffrine N, Li HL, Gascard JC (2015) The impact of freshening on phytoplankton production in the Pacific Arctic Ocean. Progress in Oceanography 131:113-125 
23. Darby D., Ortiz J, Polyak L, Lund S, Jakobsson M, Woodgate RA (2009) The role of currents and sea ice in both slowly deposited central Arctic and rapidly deposited Chukchi-Alaskan margin sediments. Global and Planetary Change 68(1-2):58-72.

24. De Vernal A, Hillaire-Marcel C, Darby DA (2005) Variability of sea ice cover in the Chukchi Sea (western Arctic Ocean) during the Holocene. Paleoceanography 20(4)

25. Dessandier PA, Bonnin J, Kim JH, Bichon S, Deflandre B, Grémare A, Sinninghe Damsté JS (2016) Impact of organic matter source and quality on living benthic foraminiferal distribution on a river-dominated continental margin: A study of the Portuguese margin. Journal of Geophysical Research: Biogeosciences 121(6):1689-1714

26. Dessandier PA, Bonnin J, Kim JH, Racine C (2018) Comparison of living and dead benthic foraminifera on the Portuguese margin: Understanding the taphonomical processes. Marine Micropaleontology 140:1-16.

27. Fetterer F, Knowles K, Meier W, Savoie M, Windnagel AK (2016) updated daily. Sea Ice Index, Version 2. [Indicate subset used]. Boulder, Colorado USA. NSIDC: National Snow and Ice Data Center

28. Fontanier C, Jorissen FJ, Licari L, Alexandre A, Anschutz P, Carbonel P (2002) Live benthic foraminiferal faunas from the Bay of Biscay: faunal density, composition, and microhabitats. Deep Sea Research Part I: Oceanographic Research Papers 49(4):751-785

29. Fontanier C, Jorissen FJ, Lansard B, Mouret A, Buscail R, Schmidt S et al (2008) Live foraminifera from the open slope between Grand Rhône and Petit Rhône canyons (Gulf of Lions, NW Mediterranean). Deep Sea Research Part I: Oceanographic Research Papers 55(11):1532-1553

30. Fransson A, Chierici M, Nojiri Y (2009) New insights into the spatial variability of the surface water carbon dioxide in varying sea ice conditions in the Arctic Ocean. Continental Shelf Research 29(10):1317-1328 
31. Goineau A (2011) Ecologie des foraminifères benthiques dans le prodelta du Rhône: Détermination de bio-indicateurs environnementaux et reconstitution historique d'une anthropisation récente. (Doctoral dissertation, Angers)

32. Goineau A, Fontanier C, Jorissen FJ, Lansard B, Buscail R, Mouret A et al (2011) Live (stained) benthic foraminifera from the Rhône prodelta (Gulf of Lion, NW Mediterranean): Environmental controls on a river-dominated shelf. Journal of Sea Research 65(1):58-75

33. Goineau A, Fontanier C, Jorissen F, Buscail R, Kerhervé P, Cathalot C et al (2012) Temporal variability of live (stained) benthic foraminiferal faunas in a river-dominated shelf-faunal response to rapid changes of the river influence (Rhône prodelta, NW Mediterranean). Biogeosciences 9(4):1367

34. Gooday AJ, Lambshead PJD (1989) Influence of seasonally deposited phytodetritus on benthic foraminiferal populations in the bathyal northeast Atlantic: the species response. Marine Ecology Progress Series:53-67

35. Gooday AJ, Bowser SS, Cedhagen T, Cornelius N, Hald M, Korsun S, Pawlowski J (2005). Monothalamous foraminiferans and gromiids (Protista) from western Svalbard: a preliminary survey. Marine Biology Research 1(4):290-312

36. Grebmeier JM, Overland JE, Moore SE, Farley EV, Carmack EC, Cooper LW et al (2006) A major ecosystem shift in the northern Bering Sea. Science 311(5766):1461-1464

37. Green KE (1960) Ecology of some Arctic foraminifera. Micropaleontology 6(1):57-78

38. Hammer $\varnothing$, Harper DAT, Ryan PD (2001) PAST: Paleontological Statistics software package for education and data analysis. Palaeontologia Electronica 4: 1-9

39. Hill V, Cota G (2005) Spatial patterns of primary production on the shelf, slope and basin of the Western Arctic in 2002. Deep Sea Research Part II: Topical Studies in Oceanography 52(2426):3344-3354 
40. Hunt Jr GL, Blanchard AL, Boveng P, Dalpadado P, Drinkwater KF, Eisner L et al (2013) The Barents and Chukchi Seas: comparison of two Arctic shelf ecosystems. Journal of Marine Systems 109:43-68

41. Husum K, Hald M, Stein R, Weißschnur M (2015) Recent benthic foraminifera in the Arctic Ocean and Kara Sea continental margin. Arktos 1:5

42. Ishman SE, Foley KM (1996) Modern benthic foraminifer distribution in the Amerasian Basin, Arctic Ocean. Micropaleontology 42(2):206-216

43. Jennings $A E$, Helgadottir $G$ (1994) Foraminiferal assemblages from the fjords and shelf of eastern Greenland. The Journal of Foraminiferal Research 24(2):123-144.

44. Johannessen OM, Bengtsson L, Miles MW, Kuzmina SI, Semenov VA, Alekseev GV et al (2004) Arctic climate change: Observed and modelled temperature and sea-ice variability. Tellus A $56(4): 328-341$

45. Jorissen FJ, De Stigter HC, Widmark JG (1995) A conceptual model explaining benthic foraminiferal microhabitats. Marine Micropaleontology 26(1-4):3-15

46. Koho KA, Kouwenhoven TJ, De Stigter HC, Van Der Zwaan GJ (2007) Benthic foraminifera in the Nazaré Canyon, Portuguese continental margin: sedimentary environments and disturbance. Marine Micropaleontology 66(1):27-51

47. Korsun S, Hald M (2000) Seasonal dynamics of benthic foraminifera in a glacially fed fjord of Svalbard, European Arctic. The Journal of Foraminiferal Research 30(4):251-271

48. Lagoe MB (1976) Species diversity of deep-sea benthic Foraminifera from the central Arctic Ocean. Geological Society of America Bulletin 87(12):1678-1683

49. Lagoe MB (1977) Recent benthic foraminifera from the central Arctic Ocean. Journal of Foraminiferal Research 7(2):106-129

50. Lagoe MB (1979) Recent benthonic foraminiferal biofacies in the Arctic Ocean. Micropaleontology:214-224 
51. Loeblich AR, Tappan H (1987) Foraminiferal genera and their classification. Van Nordstrand Reinhold co., New York.

52. Loubere P, Jacobsen B, Kristensen DK, Husum K, Jernas P, Richaud M (2011) The structure of benthic environments and the paleochemical record of foraminifera. Deep Sea Research Part I: Oceanographic Research Papers 58(5):535-545

53. Mackensen A, Hald M (1988) Cassidulina teretis Tappan and C. laevigata d'Orbigny; their modern and late Quaternary distribution in northern seas. The Journal of Foraminiferal Research 18(1):16-24

54. Martin J, Tremblay JE, Price NM (2012) Nutritive and photosynthetic ecology of subsurface chlorophyll maxima in Canadian Arctic waters. Biogeosciences 9(12):5353-5371

55. Maslanik J, Stroeve J, Fowler C, Emery W (2011) Distribution and trends in Arctic sea ice age through spring 2011. Geophysical Research Letters 38(13)

56. Meyers PA (1994) Preservation of elemental and isotopic source identification of sedimentary organic matter. Chemical geology 114(3-4):289-302

57. McRoy CP (1993) ISHTAR, the project: an overview of Inner Shelf Transfer and Recycling in the Bering and Chukchi seas. Continental Shelf Research 13(5-6):473-479

58. Moore CM, Mills MM, Arrigo KR, Berman-Frank I, Bopp L, Boyd PW et al. (2013) Processes and patterns of oceanic nutrient limitation. Nature Geoscience 6(9):701

59. Murata A, Takizawa $\mathrm{T}$ (2003) Summertime $\mathrm{CO}_{2}$ sinks in shelf and slope waters of the western Arctic Ocean. Continental Shelf Research 23(8):753-776

60. Murray JW, Bowser SS (2000) Mortality, protoplasm decay rate, and reliability of staining techniques to recognize 'living' foraminifera: a review. The Journal of Foraminiferal Research 30(1):66-70

61. Murray JW (2006) Ecology and applications of benthic foraminifera. Cambridge University Press 
62. Naidu AS, Scalan RS, Feder HM, Goering JJ, Hameedi MJ, Parker PL et al (1993) Stable organic carbon isotopes in sediments of the north Bering-south Chukchi seas, Alaskan-Soviet Arctic Shelf. Continental Shelf Research 13(5-6):669-691

63. Naidu AS, Cooper LW, Finney BP, Macdonald RW, Alexander C, Semiletov IP (2000) Organic carbon isotope ratios $\left(\delta^{13} \mathrm{C}\right)$ of Arctic Amerasian Continental shelf sediments. International Journal of Earth Sciences 89(3):522-532

64. Osterman LE, Poore RZ, Foley KM (1999). Distribution of benthic foraminifers (> $125 \mu \mathrm{m}$ ) in the surface sediments of the Arctic Ocean. US Geological Survey Bulletin 2164:1-36

65. Perrette M, Yool A, Quartly GD, Popova EE (2011) Near-ubiquity of ice-edge blooms in the Arctic. Biogeosciences 8(2):515-524

66. Pipko II, Semiletov IP, Tishchenko PY, Pugach SP, Christensen JP (2002) Carbonate chemistry dynamics in Bering Strait and the Chukchi Sea. Progress in Oceanography 55(1-2):77-94

67. Polyak L, Mikhailov V (1996) Post-glacial environments of the southeastern Barents Sea: foraminiferal evidence. Geological Society, London, Special Publications 111(1):323-337

68. Polyak L, Darby DA, Bischof JF, Jakobsson M (2007) Stratigraphic constraints on late Pleistocene glacial erosion and deglaciation of the Chukchi margin, Arctic Ocean. Quaternary Research $67(2): 234-245$

69. Polyak L, Best KM, Crawford KA, Council EA, St-Onge G (2013) Quaternary history of sea ice in the western Arctic Ocean based on foraminifera. Quaternary Science Reviews 79:145-156

70. Redfield AC, Ketchum BH, Richards FA (1963) The influence of organisms on the composition of sea-water. In Hill MN (ed), The sea 2:26-77

71. Roach AT, Aagaard K, Pease CH, Salo SA, Weingartner T, Pavlov V, Kulakov M (1995) Direct measurements of transport and water properties through the Bering Strait. Journal of Geophysical Research: Oceans 100(C9):18443-18457

72. Rodrigues CG, Hooper K, Jones PC (1980) The apertural structures of Islandiella and Cassidulina. The Journal of Foraminiferal Research 10(1):48-60 
73. Rudels B, Anderson L, Eriksson P, Fahrbach E, Jakobsson M, Jones EP et al (2012) Observations in the ocean. In Arctic Climate Change. Springer, Dordrecht, pp. 117-198

74. Sakshaug E (2004) Primary and secondary production in the Arctic Seas. In: Stein R, Macdonald RW (Ed) The organic carbon cycle in the Arctic Ocean. Heidelberg, Springer-Verlag pp 57-82

75. Schönfeld J (2001) Benthic foraminifera and pore-water oxygen profiles: a re-assessment of species boundary conditions at the western Iberian margin. Journal of Foraminiferal Research $31(2): 86-107$

76. Schönfeld J, Alve E, Geslin E, Jorissen F, Korsun S, Spezzaferri S (2012) The FOBIMO (FOraminiferal Blo-MOnitoring) initiative-Towards a standardised protocol for soft-bottom benthic foraminiferal monitoring studies. Marine Micropaleontology 94:1-13

77. Schröder-Adams CJ, Cole FE, Medioli FS, Mudie PJ, Scott DB, Dobbin L (1990) Recent Arctic shelf foraminifera; seasonally ice covered vs. perennially ice covered areas. The Journal of Foraminiferal Research 20(1):8-36

78. Scott DB, Vilks G (1991) Benthic foraminifera in the surface sediments of the deep-sea Arctic Ocean. The Journal of Foraminiferal Research 21(1):20-38

79. Scott DB, Schell T, Rochon A, Blasco S (2008) Benthic foraminifera in the surface sediments of the Beaufort Shelf and slope, Beaufort Sea, Canada: Applications and implications for past seaice conditions. Journal of Marine Systems 74(3-4):840-863

80. Seidenkrantz MS (1995) Cassidulina teretis Tappan and Cassidulina neoteretis new species (Foraminifera): stratigraphic markers for deep sea and outer shelf areas. Journal of Micropalaeontology 14(2):145-157

81. Semiletov IP (1999) Aquatic sources and sinks of $\mathrm{CO}_{2}$ and $\mathrm{CH}_{4}$ in the polar regions. Journal of the Atmospheric Sciences 56(2):286-306

82. Serreze MC, Holland MM, Stroeve J (2007) Perspectives on the Arctic's shrinking sea-ice cover. Science 315(5818):1533-1536 
83. Serreze MC, Crawford AD, Stroeve JC, Barrett AP, Woodgate RA (2016) Variability, trends, and predictability of seasonal sea ice retreat and advance in the Chukchi Sea. Journal of Geophysical Research 121(10):7308-7325

84. Shannon CE, Weaver W (1949) The Mathematical Theory of Information. Urbana: University of Illinois Press

85. Shimada K, Kamoshida T, Itoh M, Nishino S, Carmack E, McLaughlin F et al (2006) Pacific Ocean inflow: Influence on catastrophic reduction of sea ice cover in the Arctic Ocean. Geophysical Research Letters 33(8)

86. Spielhagen RF, Werner K, Sørensen SA, Zamelczyk K, Kandiano E, Budeus G et al (2011) Enhanced modern heat transfer to the Arctic by warm Atlantic water. Science 331(6016):450453

87. Springer AM, McRoY CP, Turco KR (1989) The paradox of pelagic food webs in the northern Bering Sea-II. Zooplankton communities. Continental Shelf Research 9(4):359-386

88. Stein R, Grobe H, Wahsner M (1994) Organic carbon, carbonate, and clay mineral distributions in eastern central Arctic Ocean surface sediments. Marine Geology 119(3-4):269-285

89. Steinsund PI, Hald M (1994) Recent calcium carbonate dissolution in the Barents Sea: paleoceanographic applications. Marine Geology 117(1-4):303-316

90. Stroeve JC, Serreze MC, Holland MM, Kay JE, Malanik J, Barrett AP (2012) The Arctic's rapidly shrinking sea ice cover: a research synthesis. Climatic Change 110(3-4):1005-1027

91. Swift JH, Jones EP, Aagaard K, Carmack EC, Hingston M, Macdonald RW et al (1997) Waters of the Makarov and Canada basins. Deep Sea Research Part II: Topical Studies in Oceanography 44(8):1503-1529

92. Tremblay JE, Simpson K, Martin J, Miller L, Gratton Y, Barber D, Price NM (2008) Vertical stability and the annual dynamics of nutrients and chlorophyll fluorescence in the coastal, southeast Beaufort Sea. Journal of Geophysical Research: Oceans 113(C7) 
93. Tremblay JE, Anderson LG, Matrai P, Coupel P, Bélanger S, Michel C, Reigstad M (2015) Global 676 67 7678 8

and regional drivers of nutrient supply, primary production and $\mathrm{CO}_{2}$ drawdown in the changing Arctic Ocean. Progress in Oceanography 139:171-196

94. Vilks G (1969) Recent foraminifera in the Canadian Arctic. Micropaleontology:35-60

95. Vilks G (1989) Ecology of recent foraminifera on the Canadian continental shelf of the Arctic Ocean. In The Arctic Seas. Springer, Boston, MA, pp 497-569

96. Walton WR (1952) Techniques for recognition of living foraminifera. Contribution of the Cushman Foundation for Foraminiferal Research 3(2):56-60

97. Wang J, Cota GF, Comiso JC (2005) Phytoplankton in the Beaufort and Chukchi Seas: Distribution, dynamics, and environmental forcing. Deep Sea Research Part II: Topical Studies in Oceanography 52(24-26):3355-3368

98. Wassmann P, Bauernfeind E, Fortier M, Fukuchi M, Hargrave B, Moran B, Noji Th, Nöthig EM, Peinert R, Sasaki H, Shevchenko V (2004) Particulate organic carbon flux to the sea floor. In: Stein R, Macdonald RM (Ed) In: The Organic Carbon Cycle in the Arctic Ocean. Springer-Verlag, Heidelberg-Berlin-New York, pp 101-138

99. Wassmann P (2011) Arctic marine ecosystems in an era of rapid climate change. Progress in Oceanography 1(90):1-17

100. Weingartner TJ, Cavalieri DJ, Aagaard K, Sasaki Y (1998) Circulation, dense water formation, and outflow on the northeast Chukchi shelf. Journal of Geophysical Research: Oceans 103(C4):76477661

101. Weingartner TJ, Danielson S, Sasaki Y, Pavlov V, Kulakov M (1999) The Siberian Coastal Current: A wind-and buoyancy-forced Arctic coastal current. Journal of Geophysical Research: Oceans 104(C12):29697-29713

102. Wollenburg JE, Mackensen A (1998a) Living benthic foraminifers from the central Arctic Ocean: faunal composition, standing stock and diversity. Marine Micropaleontology 34(3):153-185 
103. Wollenburg JE, Mackensen A (1998b) On the vertical distribution of living (Rose Bengal stained) benthic foraminifers in the Arctic Ocean. The Journal of Foraminiferal Research 28(4):268-285

104. Wollenburg JE, Kuhnt W (2000) The response of benthic foraminifers to carbon flux and primary production in the Arctic Ocean. Marine Micropaleontology 40(3):189-231

105. Woodgate RA, Aagaard K, Weingartner TJ (2005) A year in the physical oceanography of the Chukchi Sea: Moored measurements from autumn 1990-1991. Deep Sea Research II: Topical Studies in Oceanography 52(24-26):3116-3149

106. Woodgate RA, Aagaard K (2005) Revising the Bering Strait freshwater flux into the Arctic Ocean. Geophysical Research Letters 32(2)

107. Woodgate RA, Aagaard K, Weingartner TJ (2006) Interannual changes in the Bering Strait fluxes of volume, heat and freshwater between 1991 and 2004. Geophysical Research Letters 33(15)

108. Woodgate RA, Weingartner T, Lindsay R (2010) The 2007 Bering Strait oceanic heat flux and anomalous Arctic sea-ice retreat. Geophysical Research Letters 37(1)

109. Woodgate RA, Weingartner TJ, Lindsay R (2012) Observed increases in Bering Strait oceanic fluxes from the Pacific to the Arctic from 2001 to 2011 and their impacts on the Arctic Ocean water column. Geophysical Research Letters 39(24)

110. Yun MS, Whitledge TE, Gong M, Lee SH (2014) Low primary production in the Chukchi Sea shelf, 2009. Continental Shelf Research 76:1-11

111. Yun MS, Whitledge TE, Stockwell D, Son SH, Lee JH, Park JW et al (2016) Primary production in the Chukchi Sea with potential effects of freshwater content. Biogeosciences 13(3):737 


\section{Table and figure captions}

722 Table 1 Station numbers, types, locations and water depths

723 Fig.1 Bathymetric map of the Chukchi Sea with sampling locations, main features of the surface and intermediate circulation, and mean sea-ice extent in August 2015 (white line) and September 2015 (white dotted line). The circulation is adapted from Rudels and al. [73]. For the surface waters, lowsalinity currents derived from Pacific water are indicated by green arrows and cold polar and arctic currents by blue arrows. Circulation of intermediate waters is shown by black dotted arrows. AC: Anadyr Current; ACC: Alaskan Coastal Current; BG: Beaufort Gyre; BSW: Bering Sea Water; SCC: Siberian Coastal Current; TPD: Transpolar Drift. Monthly sea-ice extent is from NSIDC [27] and bathymetry is from IBCAO, WGS84

Fig.2 Water column profiles of temperature, salinity (a) and chlorophyll a (b) at Sts. 01A, 03,02 and 04. Pacific water mass is underlined in green, Atlantic Intermediate Water in red and Artic Deep Water in blue

Fig.3 Downcore (topmost $2 \mathrm{~cm}$ ) profiles of median sediment grain size $D_{50}(\mu \mathrm{m})$, total organic carbon content (TOC, wt. \%), total nitrogen content (TN, wt. \%), $\delta^{13} \mathrm{Corg}_{\text {org }}$ (\% VPDB) and $\mathrm{C} / \mathrm{N}$ ratio at all stations

Fig.4 Downcore ${ }^{210} \mathrm{~Pb}_{\mathrm{xs}}$ profile measured at St. $01 \mathrm{~A}$

Fig.5 Ecological indices describing foraminiferal assemblages at all stations for the $63-150 \mu \mathrm{m}$ (topmost centimetre, grey bars) and $>125 \mu \mathrm{m}$ size fractions (topmost $5 \mathrm{~cm}$, black bars). (a) Foraminiferal abundances; (b) Number of species S; (c-d) Shannon $\left(H^{\prime}\right)$ and Evenness (E) indices

Fig.6 Proportion of agglutinated versus calcareous species at all stations for the 63-125 $\mu \mathrm{m}$ size fraction (a) and the $>125 \mu \mathrm{m}$ size fraction (b)

Fig.7 Foraminiferal relative abundances of major species ( $>5 \%$ of the total living benthic foraminifera assemblage) for the $63-125 \mu \mathrm{m}$ (a) and the $>125 \mu \mathrm{m}$ (b) size fractions. Living standing stock (number in the central area of the pie charts) are standardized for a surface area of $100 \mathrm{~cm}^{2}$. Species representing less than $5 \%$ are grouped in the category "others" 
747 Fig.8 Vertical distribution of major species of living benthic foraminifera (>125 $\mu \mathrm{m}$ ) in terms of faunal 1

2748 density (ind. $/ 50 \mathrm{~cm}^{3}$ ) in the topmost $5 \mathrm{~cm}$

3

749 Fig.9 Density of living (blue) and dead (orange) benthic foraminifera in the first centimetre of 750 sediment for each station and each size fraction. 
Table 1 Station numbers, types, locations and water depths

\begin{tabular}{cccccc}
\hline Cruise & Sample & Sampling & Longitude & Latitude & Water \\
& station & device & & depth $(\mathrm{m})$ \\
\hline ARA06C & $01 \mathrm{~A}$ & Multicorer & -166.44 & 73.62 & 110 \\
ARA06C & 02 & Boxcorer & -161.17 & 76.60 & 2100 \\
ARA06C & 03 & Multicorer & 181.01 & 76.33 & 750 \\
ARA06C & 04 & Multicorer & -173.23 & 78.84 & 2300 \\
ARA06C & 05 & Boxcorer & 179.50 & 75.60 & 350 \\
\hline
\end{tabular}


(a)
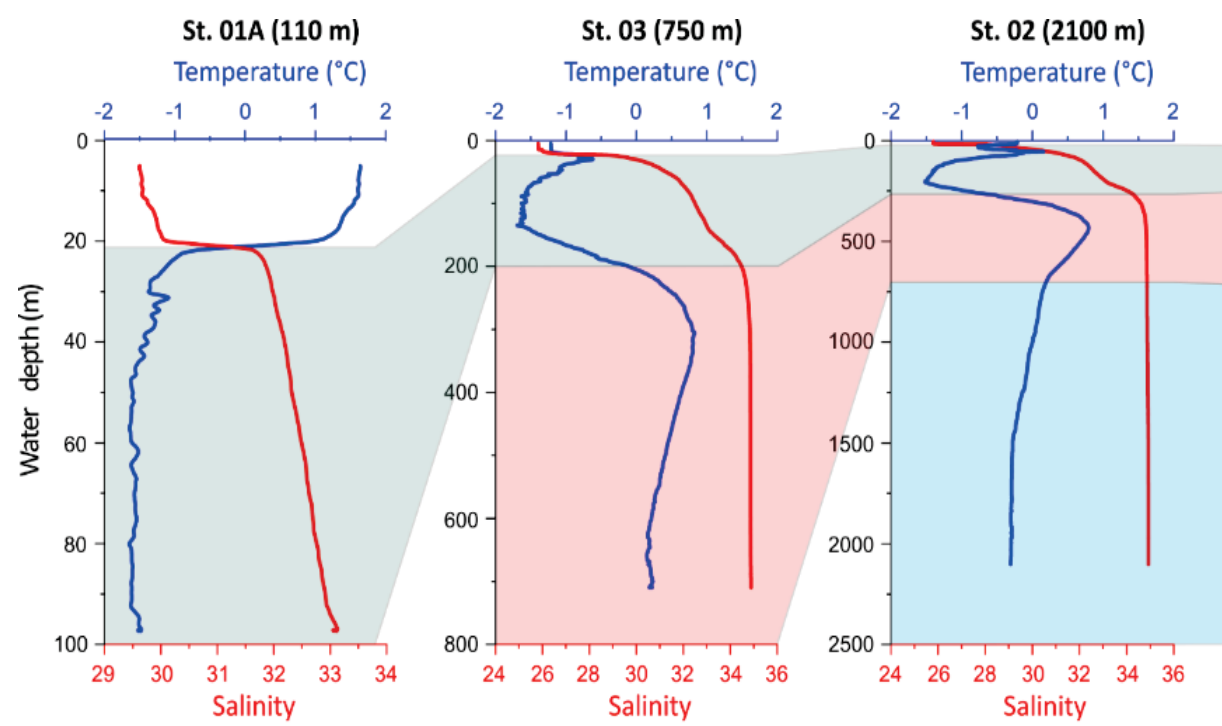

St. $04(2300 \mathrm{~m})$

Temperature $\left({ }^{\circ} \mathrm{C}\right)$

(b)
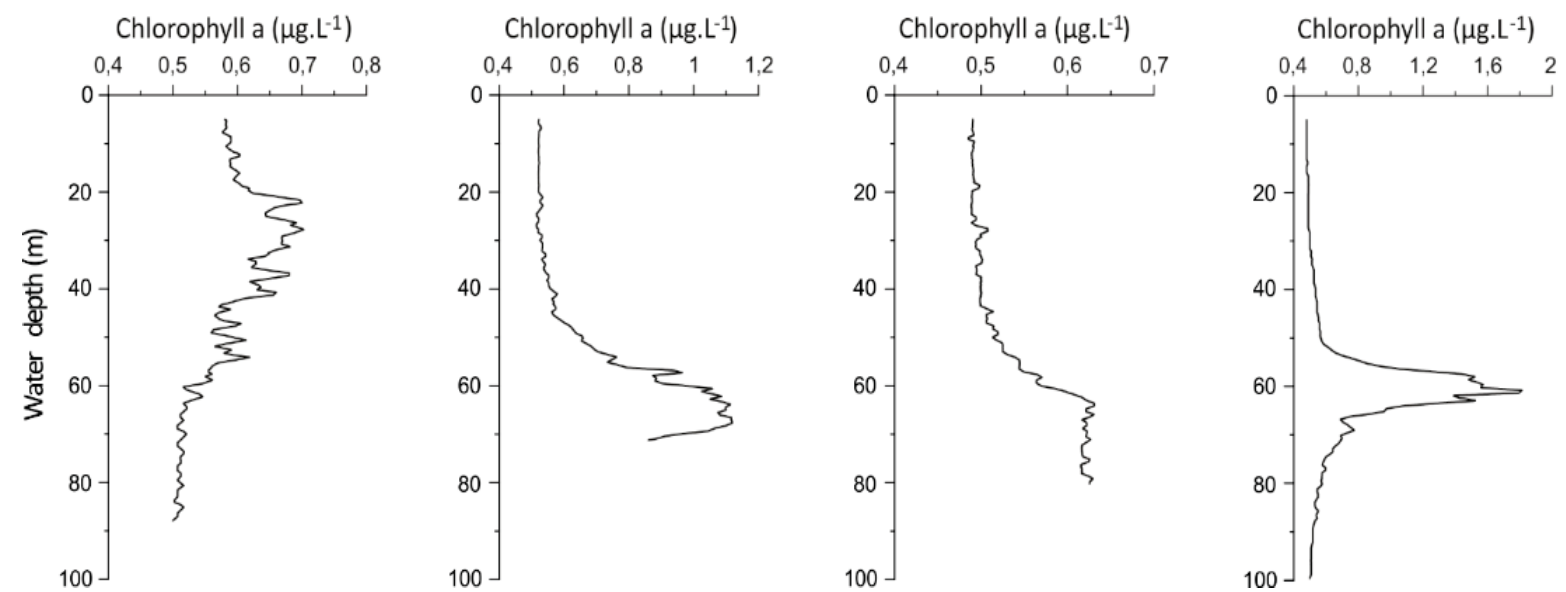

Fig2 

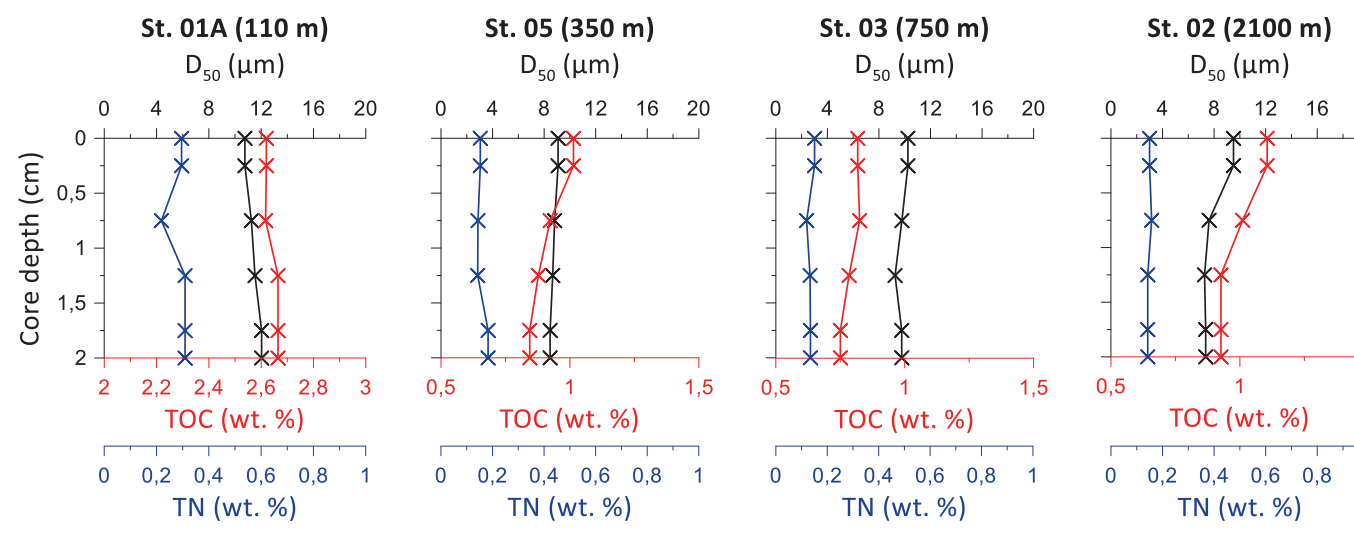

\section{St. $04(2300 \mathrm{~m})$}

$D_{50}(\mu \mathrm{m})$

$\mathrm{D}_{50}(\mu \mathrm{m})$
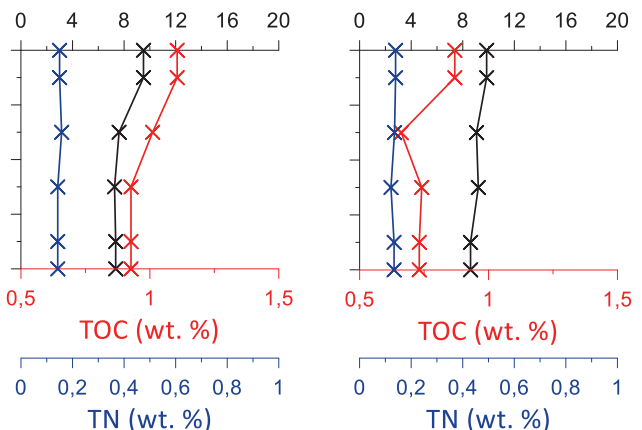

$\begin{array}{lcl}0,5 & 1 & 1,5\end{array}$

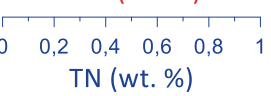

$\delta^{13} \mathrm{C}_{\text {org }}$ (\%。 VPDB)

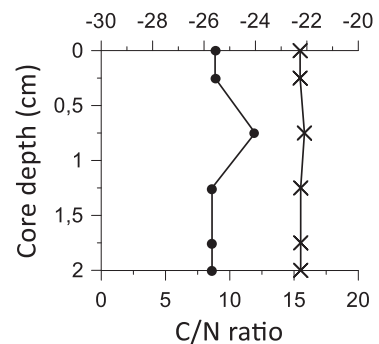

$\delta^{13} \mathrm{C}_{\text {org }}$ (\% VPDB)

$\delta^{13} \mathrm{C}_{\text {org }}$ (\% VPDB)
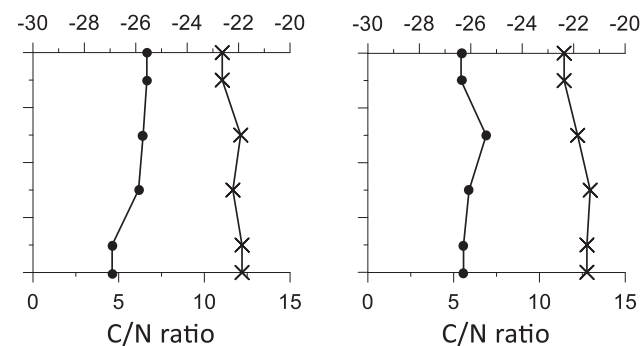

$\delta^{13} C_{\text {org }}$ (\%o VPDB)

$\delta^{13} C_{\text {org }}$ (\% VPDB)

$\begin{array}{llllll}-30 & -28 & -26 & -24 & -22 & -20\end{array}$

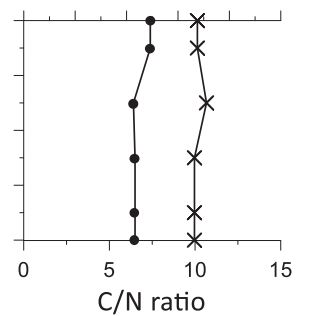

$\begin{array}{llllll}-30 & -28 & -26 & -24 & -22 & -20\end{array}$

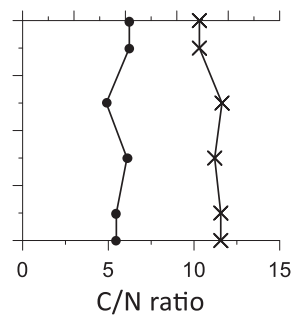

Fig3 


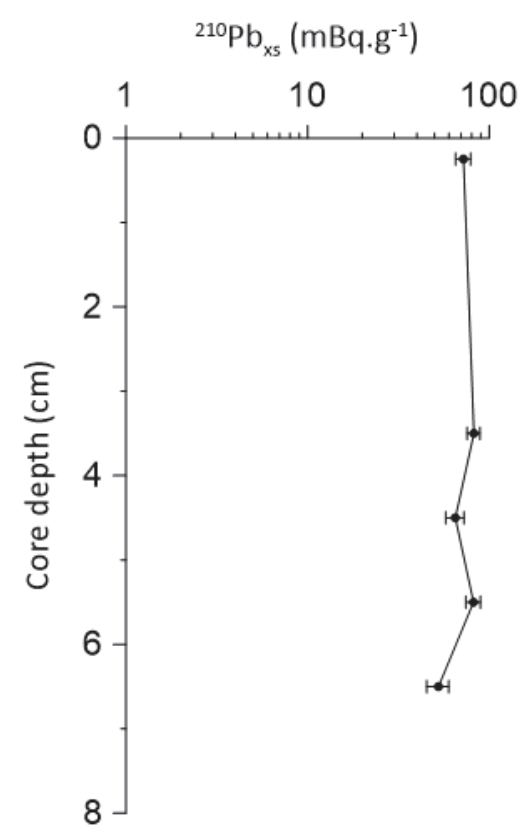

Fig4 
(a)

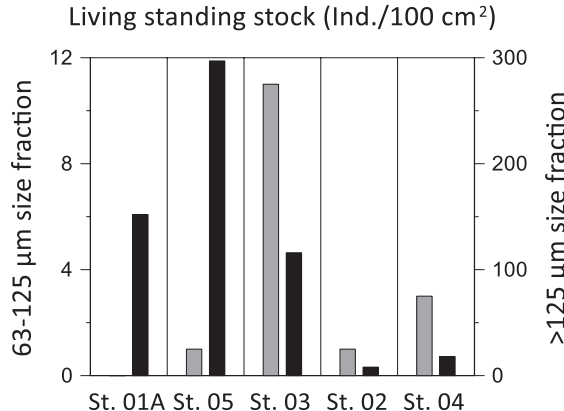

(c)

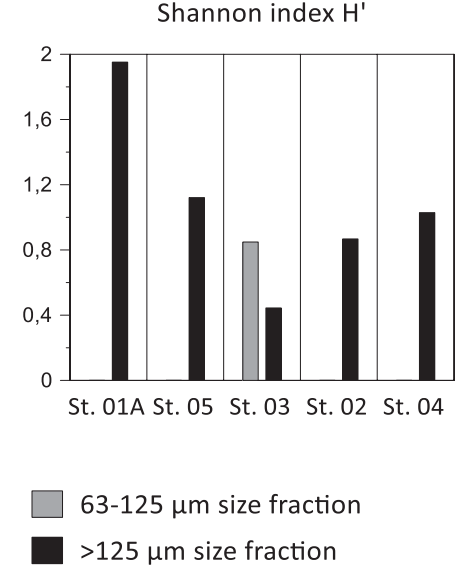

(b) Species richness $\mathrm{S}$

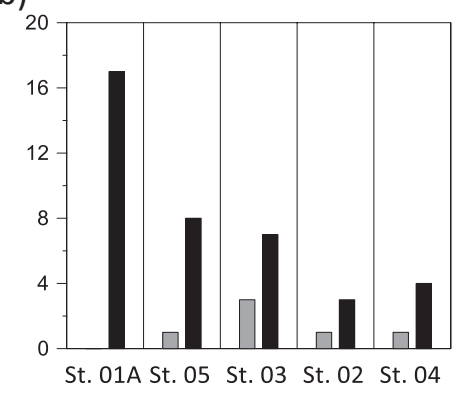

(d)

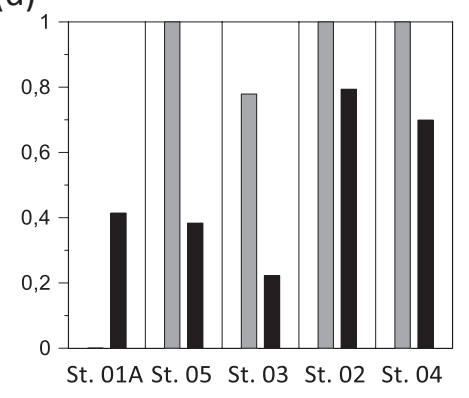

Fig5 
(a) \% agglutinated vs calcareous species $(63-125 \mu \mathrm{m})$

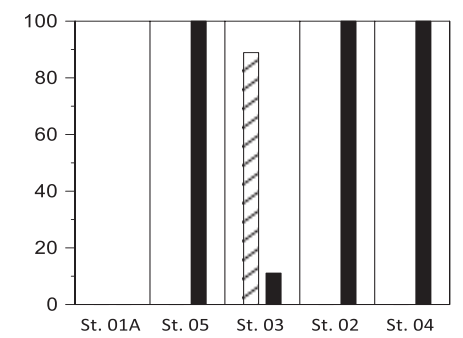

(b) \% agglutinated vs calcareous species (>125 $\mu \mathrm{m}$ )

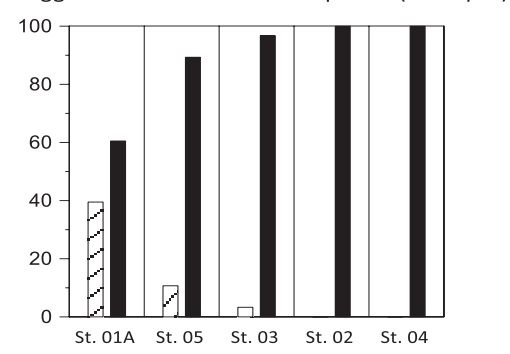

$\varnothing$ agglutinated species

calcareous species

Fig6 


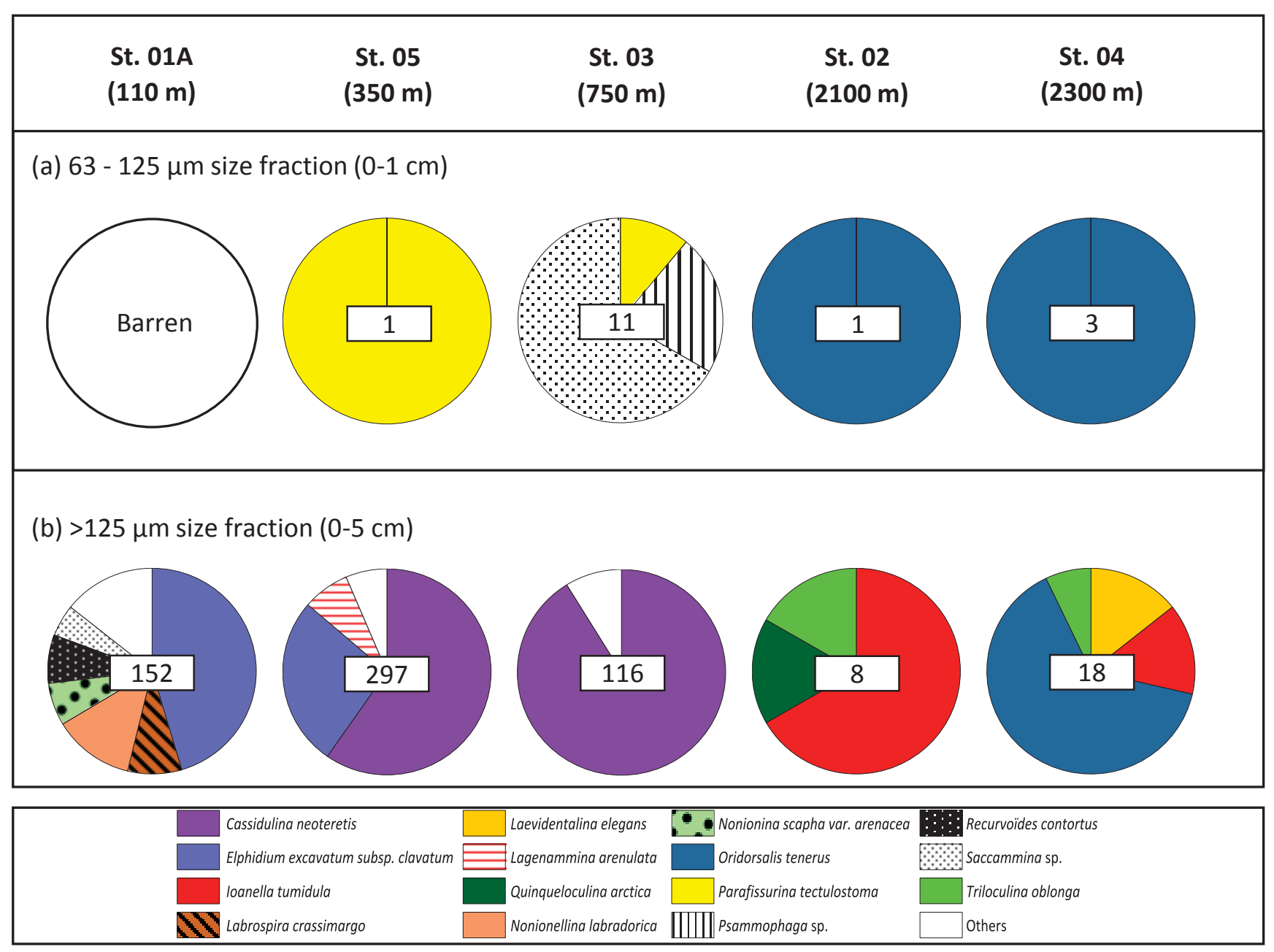

Fig7 


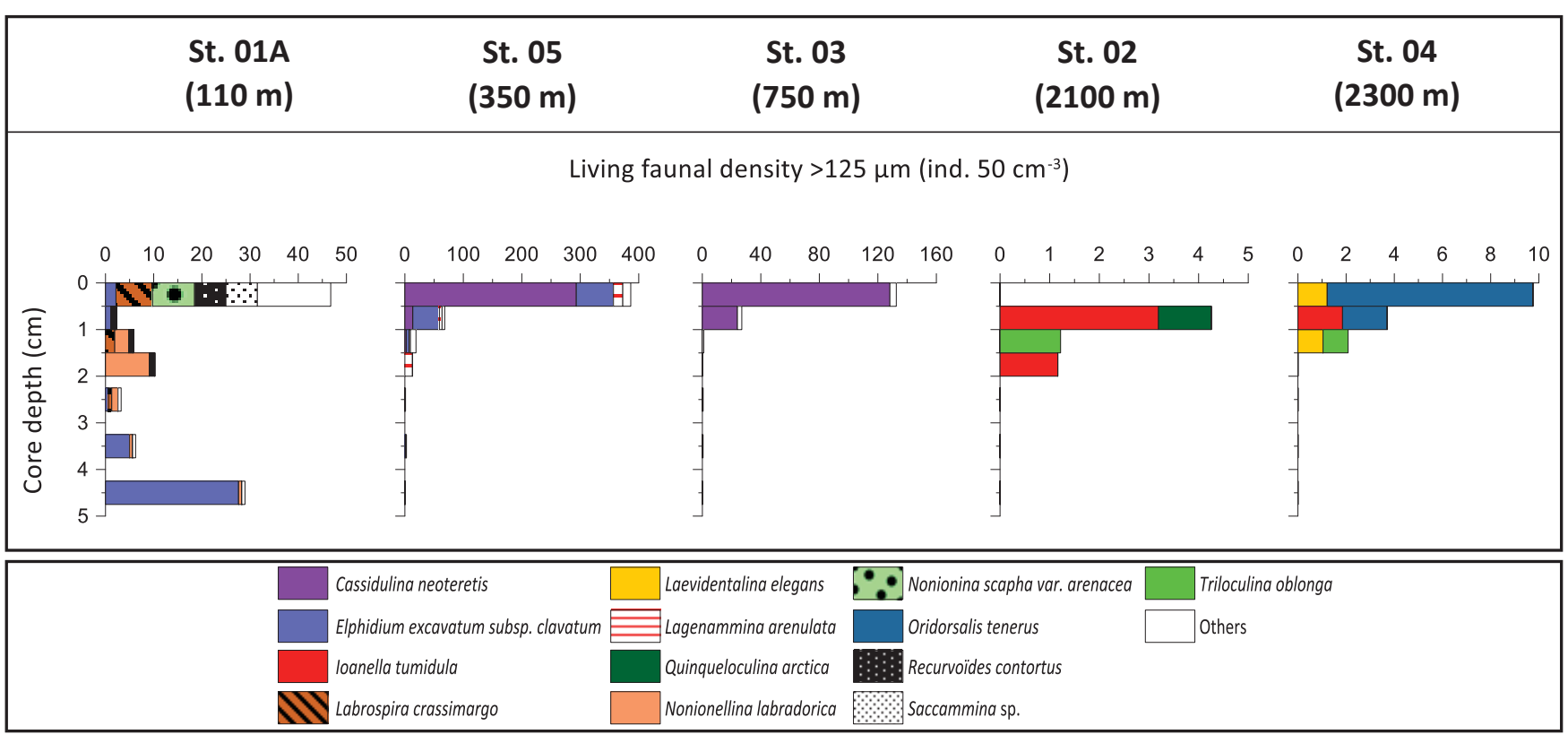

Fig8 

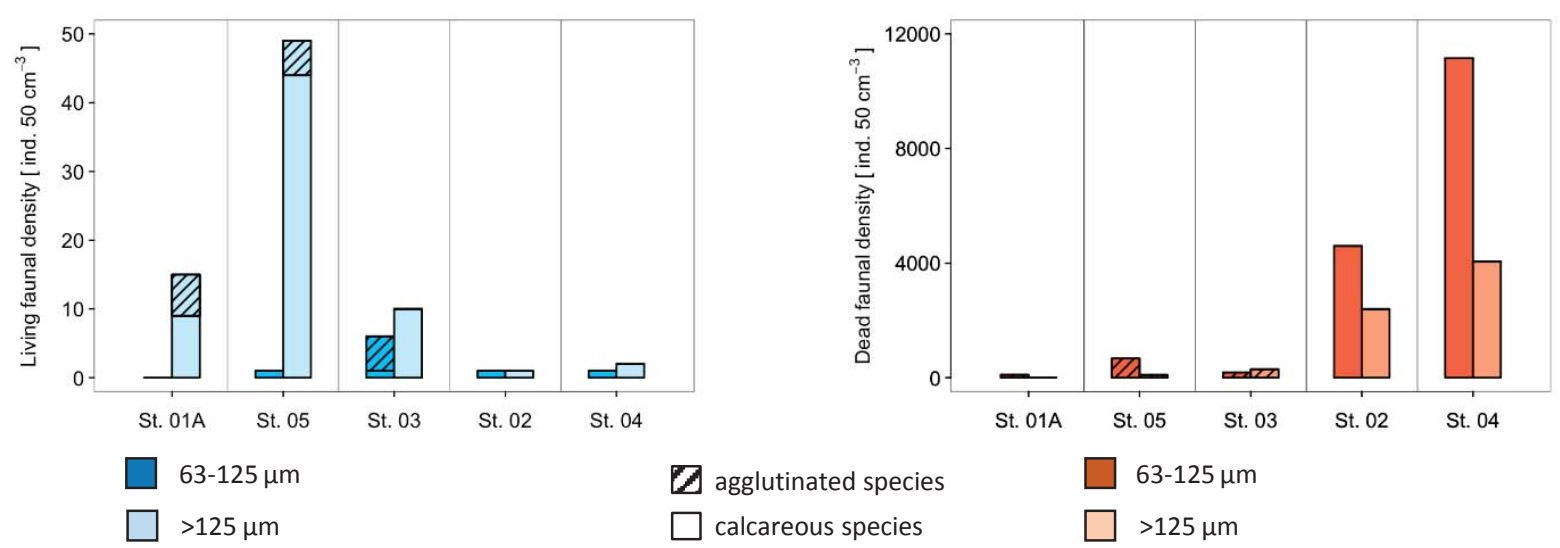

Fig9 


\section{Appendices}

Appendix 1 Taxonomic reference list of major taxa

Cassidulina neoteretis Seidenkrantz, 1995

Elphidium excavatum subsp. clavatum Cushman, 1930

loanella tumidula (Brady, 1884)

Labrospira crassimargo (Norman, 1892)

Laevidentalina elegans (d'Orbigny, 1846)

Lagenammina arenulata (Skinner, 1961)

Quinqueloculina arctica Cushman, 1933

Nonionellina labradorica (Dawson, 1860)

Nonionina scapha var. arenacea Heron-Allen and Earland, 1922

Oridorsalis tenerus (Brady, 1884)

Parafissurina tectulostoma Loeblich and Tappan, 1953

Psammophaga sp. Arnold, 1982

Recurvoides contortus Earland, 1934

Saccammina sp. Sars, 1869

Triloculina oblonga (Montagu, 1803) 


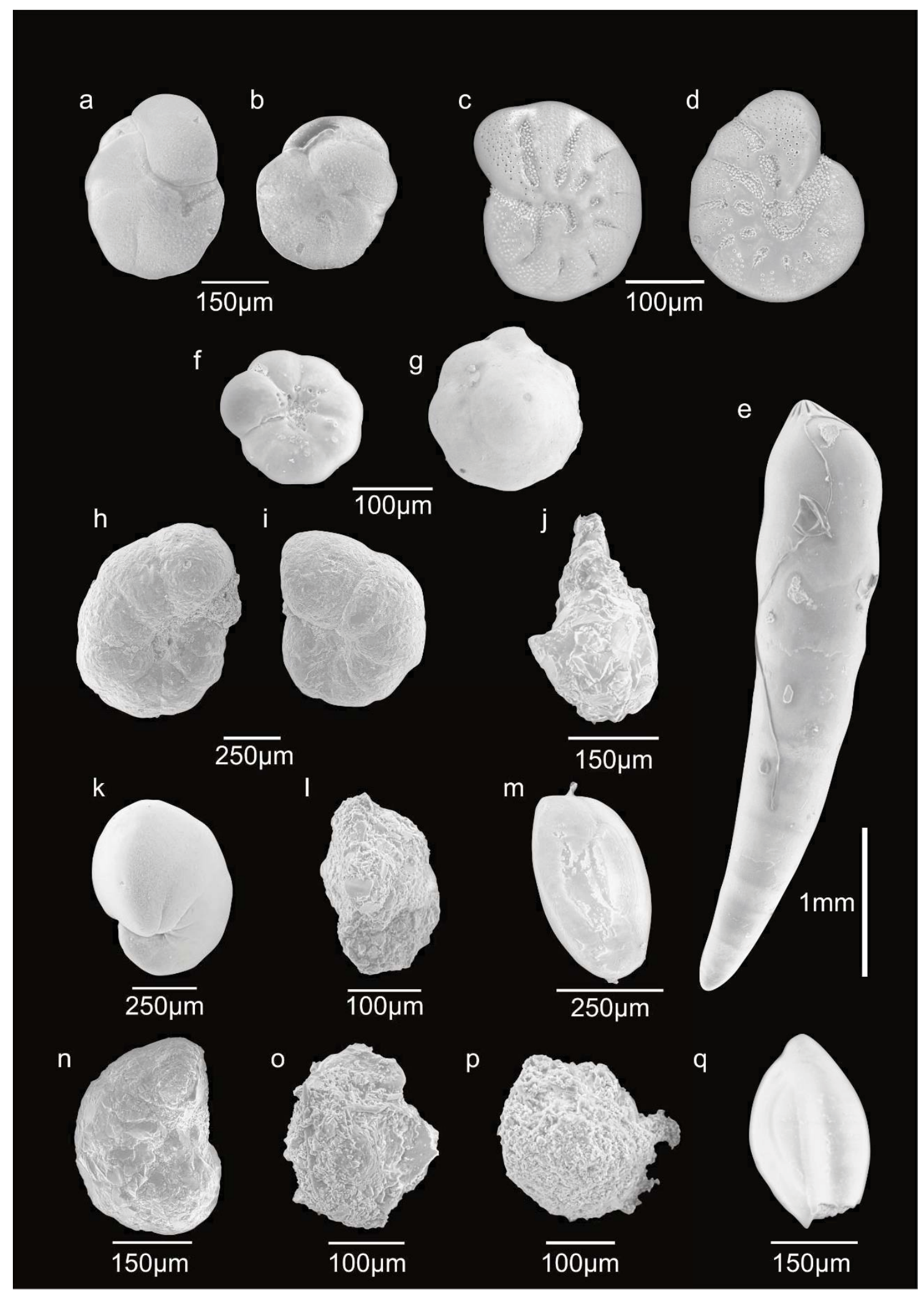

a-b : Cassidulina neoteretis; c-d : Elphidium excavatum subsp. clavatum; e : Laevidentalina elegans; $\mathbf{f}$ : loanella tumidula (ombilical side); $\mathbf{g}$ : loanella tumidula (spiral side); h-I : Labrospira crassimargo; $\mathbf{j}$ : Lagenammina arenulata; k : Nonionellina labradorica; I : Nonionina scapha var. arenacea; $\mathbf{m}$ : Triloculina oblonga; $\mathbf{n}$ : Recurvoïdes contortus; o-p : Saccammina sp.; q : Quinqueloculina arctica 


\section{Appendix 3}

Table 2. Number of major living (stained) benthic foraminiferal species (representing $>5 \%$ in at least one sample), number and densities of total living and dead fauna for each station and each size fraction.

\begin{tabular}{|c|c|c|c|c|c|c|c|c|c|c|}
\hline Station & & & & & 0 & & $\mathrm{c}$ & & 0 & \\
\hline Size fraction & $\begin{array}{c}63-125 \\
\mu \mathrm{m}\end{array}$ & $\begin{array}{c}>125 \\
\mu \mathrm{m}\end{array}$ & $\begin{array}{c}63-125 \\
\mu \mathrm{m}\end{array}$ & $\begin{array}{c}>125 \\
\mu \mathrm{m}\end{array}$ & $\begin{array}{c}\text { 63-125 } \\
\mu \mathrm{m}\end{array}$ & $\begin{array}{c}>125 \\
\mu \mathrm{m}\end{array}$ & $\begin{array}{c}63-125 \\
\mu \mathrm{m}\end{array}$ & $\begin{array}{l}>125 \\
\mu \mathrm{m}\end{array}$ & $\begin{array}{c}\text { 63-125 } \\
\mu \mathrm{m}\end{array}$ & $\begin{array}{l}>125 \\
\mu \mathrm{m}\end{array}$ \\
\hline $\begin{array}{l}\text { Cassidulina } \\
\text { neoteretis }\end{array}$ & 0 & 0 & 0 & 0 & 0 & 83 & 0 & 0 & 0 & 139 \\
\hline $\begin{array}{l}\text { Elphidium } \\
\text { excavatum subsp. } \\
\text { clavatum }\end{array}$ & 0 & 54 & 0 & 0 & 0 & 0 & 0 & 0 & 0 & 62 \\
\hline loanella tumidula & 0 & 0 & 0 & 4 & 0 & 0 & 0 & 2 & 0 & 0 \\
\hline $\begin{array}{l}\text { Labrospira } \\
\text { crassimargo }\end{array}$ & 0 & 10 & 0 & 0 & 0 & 0 & 0 & 0 & 0 & 0 \\
\hline $\begin{array}{l}\text { Laevidentalina } \\
\text { elegans }\end{array}$ & 0 & 0 & 0 & 0 & 0 & 0 & 0 & 2 & 0 & 0 \\
\hline $\begin{array}{l}\text { Lagenammina } \\
\text { arenulata }\end{array}$ & 0 & 0 & 0 & 0 & 0 & 1 & 0 & 0 & 0 & 17 \\
\hline $\begin{array}{l}\text { Quinqueloculina } \\
\text { arctica }\end{array}$ & 0 & 0 & 0 & 1 & 0 & 0 & 0 & 0 & 0 & 0 \\
\hline $\begin{array}{l}\text { Nonionellina } \\
\text { labradorica }\end{array}$ & 0 & 15 & 0 & 0 & 0 & 0 & 0 & 0 & 0 & 0 \\
\hline $\begin{array}{l}\text { Nonionina scapha } \\
\text { var. arenacea }\end{array}$ & 0 & 8 & 0 & 0 & 0 & 0 & 0 & 0 & 0 & 0 \\
\hline Oridorsalis tenerus & 0 & 0 & 1 & 0 & 0 & 0 & 2 & 9 & 0 & 0 \\
\hline $\begin{array}{l}\text { Parafissurina } \\
\text { tectulostoma }\end{array}$ & 0 & 0 & 0 & 0 & 1 & 0 & 0 & 0 & 1 & 0 \\
\hline Psammophaga sp. & 0 & 0 & 0 & 0 & 2 & 0 & 0 & 0 & 0 & 0 \\
\hline $\begin{array}{l}\text { Recurvoïdes } \\
\text { contortus }\end{array}$ & 0 & 9 & 0 & 0 & 0 & 0 & 0 & 0 & 0 & 0 \\
\hline Saccammina sp. & 0 & 6 & 0 & 0 & 6 & 0 & 0 & 0 & 0 & 0 \\
\hline Triloculina oblonga & 0 & 0 & 0 & 1 & 0 & 1 & 0 & 1 & 0 & 0 \\
\hline Others & 0 & 17 & 0 & 0 & 0 & 6 & 0 & 0 & 0 & 15 \\
\hline $\begin{array}{l}\text { No of living } \\
\text { specimens counted }\end{array}$ & 0 & 119 & 1 & 6 & 9 & 91 & 2 & 14 & 1 & 233 \\
\hline $\begin{array}{l}\text { Living } \\
\text { specimens } / 50 \mathrm{~cm}^{3}\end{array}$ & 0 & 14 & 0.5 & 1 & 6 & 11 & 1 & 2 & 0.9 & 50 \\
\hline $\begin{array}{l}\text { No of dead } \\
\text { specimens counted }\end{array}$ & 186 & 54 & 8552 & 19056 & 266 & 2526 & 21184 & 34576 & 298 & 470 \\
\hline $\begin{array}{l}\text { Dead } \\
\text { specimens } / 50 \mathrm{~cm}^{3}\end{array}$ & 103 & 6 & 4598 & 2394 & 182 & 294 & 11149 & 4058 & 677 & 100 \\
\hline
\end{tabular}

